\title{
ACERCA DE LA FUNDAMENTACIÓN DE LA OBLIGATORIEDAD DE LOS CONTRATOS: AUTONOMÍA Y DERECHO PRIVADO*
}

\author{
ABOUT THE FOUNDATIONS OF THE BINDING \\ FORCE OF THE CONTRACTS: AUTONOMY AND PRIVATE LAW \\ À PRopos DE LA FONDAMENTATION DE LA FORCE OBLIGATOIRE \\ DES CONTRATS: AUTONOMIE ET Droit Privé
}

Esteban Pereira Fredes ${ }^{* *}$

\begin{abstract}
RESUMEN
El artículo analiza en forma crítica la discusión acerca de la justificación normativa de la fuerza obligatoria del contrato, consagrada en el artículo 1545 del Código Civil chileno. Se presentan los esquemas de comprensión de la regla contractual, distinguiendo entre modelos no-normativos y modelos normativos. El contrato constituye una noción institucional que requiere de consideraciones justificativas y no meramente explicativas. Tal esfuerzo debe desvincularse de la noción de voluntad que ha enfrentado dificultades frente al incremento de las intervenciones legislativas, que caracterizan al escenario contractual que rige desde inicios del siglo XX. Se sugiere la pertinencia explicativa de la autonomía personal, articulándola a partir de la estructura interna y las reglas secundarias que conforman al derecho privado.

PALABRAS CLAVE: Contrato - Fuerza obligatoria de los contratos - Autonomía personal Derecho privado

ABSTRACT

The article critically examines the discussion regarding the normative justification of the binding force of contracts, set forth in article 1545 of the Chilean Civil Code. The theoretical schemes to understand the contractual rule are presented herein, distinguishing between non-normative and normative models. The contract is an institutional notion that requires justification and not merely explanatory considerations. Such effort should be separated from the notion of will, which has faced difficulties, considering the increased legislative interventions, which characterize the governing contractual scenario since the early XX
\end{abstract}

\footnotetext{
* Artículo recibido el 30 de octubre de 2014 y aceptado para su publicación el 15 de noviembre de 2014.

** Abogado. Licenciado en Ciencias Jurídicas y Sociales de la Universidad de Chile. Magíster en Derecho con Mención en Derecho Privado de la Universidad de Chile. Profesor Instructor en la Facultad de Derecho de la Universidad Adolfo Ibáñez, Santiago, Chile. Correo electrónico: esteban.pereira@uai.cl.

El presente artículo constituye una versión adaptada de la tesis para obtener el grado de Magíster en Derecho con Mención en Derecho Privado, Justificación normativa de la obligatoriedad del vínculo contractual, Facultad de Derecho, Universidad de Chile, 2014. Agradezco a Rodrigo Barcia Lehmann por su enorme apoyo en la dirección de dicha investigación. Asimismo, a las valiosas observaciones que formularon Maricruz Gómez de la Torre, Joaquín García-Huidobro Correa, M. E. Orellana Benado y Carlos Peña González, quienes integraron la comisión de defensa de la tesis. Finalmente, a Alberto Pino Emhart, quien enriqueció sustantivamente la investigación gracias a sus agudos comentarios.
} 
century. The explanatory relevance of personal autonomy is suggested herein, an argument articulated from the internal structure and secondary rules that constitute private law.

KEYWORDS: Contract - Binding force of the contract - Personal autonomy - Private law

RÉSUMÉ

Cette chronique fait une analyse critique du débat à propos de la justification normative de la force obligatoire du contrat consacrée dans l'article 1545 du Code civil chilien. Il s'agit d'exposer les schémas de comprension de la règle contractuelle, par la voie de distinguer parmis les modèles no-normatifs et modèles normatifs. Le contrat est une notion institutionnelle don ton croit il es nécessaire certaines considérations justificatives et non seulement explicatives. Tel effort doit se détacher de la notion de volonté qui a eu quelques soucis à propos des interventions législatives qui ont formé les traits du scénario contractuel depuis le debut du XX siècle. On propose la pertinence explicative de l'autonomie personnelle, en l'articulant à partir de la structure interne et les règles secondaires qui ont formé le droit privé.

MOTS CLÉS: Contrat - Force obligatoire du contrat - Autonomie personnelle - Droit privé

\section{INTRODUCCIÓN}

El contrato constituye una de las instituciones sociales de mayor complejidad y relevancia en nuestra realidad social. La peculiaridad del vínculo contractual descansa en su configuración moderna, según la cual su existencia es instrumental a la consecución de ciertos objetivos, considerados como valiosos por la comunidad. Dada esta consideración, los sistemas jurídicos privados consagran una regla jurídica, brindando operatividad a la fuerza vinculante del contrato. La relación contractual es obligatoria para las partes contratantes, no obstante produzca efectos perjudiciales en sus patrimonios. El artículo 1545 del Código Civil reconoce la vigencia del pacta sunt servanda en el esquema civil nacional y, de ahí, que nuestros contratos legalmente celebrados obliguen a los contratantes de un modo incondicionado, como si se tratare del cumplimiento de una ley.

Tradicionalmente la dogmática civil ha extraviado el problema decisivo que enfrenta una regla contractual como la esgrimida por Andrés Bello, limitándose a dar cuenta de la existencia de nuestro articulado y evaluando sus alcances. Sin embargo, la identidad institucional del contrato exige proveer de razones justificativas sobre su existencia y, principalmente, justificar normativamente su obligatoriedad. Desde el prisma de la filosofía del derecho privado, no basta con evidenciar el reconocimiento de la regla jurídica que la consagra, sino que es necesario transparentar por qué es razonable que exista una regla contractual, como la esgrimida en el artículo 1545 del texto de $1855^{1}$. Si fuere necesario formular una justificación

\footnotetext{
${ }^{1}$ Respecto a la identidad contemporánea de la filosofía del derecho privado, puede consultarse WEINRIB, Ernest J. (2012). The Idea of Private Law. Oxford: Oxford University Press, pp. ix-xx; 1-21; LuCY, William (2007). Philosophy of Private Law. Oxford: Oxford University Press, pp. 1-44; y ZipURsKY, Benjamin C. (2004). "Philosophy of Private Law". En: The Oxford Handbook of Jurisprudence \& Philosophy of Law. Oxford: Oxford University Press, pp. 623-655.
} 
valorativa de la fuerza vinculante del contrato, se requiere una aproximación que realice tal empresa en términos satisfactorios.

En lo que sigue, se desarrollará la problemática asociada a la legitimación moral del vínculo contractual, evaluándola a luz del escenario contractual contemporáneo bajo el cual la voluntad de las partes ha perdido su relevancia frente a la irrupción de la intervención legislativa promovida desde inicios del siglo XX. El presente trabajo tiene por objetivo formular una propuesta de justificación normativa de la obligatoriedad del contrato.

En la primera sección, se desarrollarán los problemas relativos a la fuerza obligatoria del vínculo contractual, a partir de sus alcances y reconocimiento bajo nuestro sistema jurídico privado. A continuación, se efectuará un examen de los modelos explicativos que se encuentran en disputa para dar cuenta de una regla contractual según la cual se exige el cumplimiento incondicionado de los contratos. Dicha tarea se realizará a partir de una fractura entre esquemas normativos y alternativas no-normativas de comprensión. La especial atención desplegada hacia las intuiciones de Charles Fried se explica por su decisiva influencia como fundamento paradigmático de la fuerza obligatoria y, además, por los insumos que brindará durante la sección final de este trabajo.

En la segunda sección, se analizará la necesidad de una justificación normativa de la fuerza vinculante de la relación contractual, sugiriendo la pertinencia de un esquema que procure dar cuenta del artículo 1545 del Código Civil en términos valorativos. Se implementará la comprensión de Dori Kimel sobre la autonomía personal en su teoría liberal del contrato, recuperando el rol fundamental que puede cumplir la noción de autonomía para otorgar legitimidad moral a nuestras relaciones contractuales, no obstante el contexto de intervención legislativa que interrumpe las pretensiones de los agentes en sus vínculos autónomos. Bajo estas consideraciones, se formulará una propuesta de justificación normativa de la obligatoriedad del contrato, que sea compatible con la regulación contractual contemporánea y, de igual modo, consistente con la estructura normativa del derecho privado como un conjunto de reglas secundarias, que confieren potestades a los particulares para materializar sus planes de vida.

\section{Aproximaciones a la obligatoriedad del VÍNCUlo CONTRACtUAL}

\subsection{Fuerza vinculante del contrato: concepto y principios asociados}

El contrato, de igual manera que toda institución jurídica situada bajo el prisma de una comprensión moderna sobre el fenómeno jurídico, supone una creación voluntaria de los partícipes de la práctica jurídica ${ }^{2}$. Desde esta perspectiva de análisis, el derecho consiste en un conjunto de conceptos, prácticas e instituciones

2 Para el desarrollo de dos comprensiones sobre el fenómeno jurídico, asociadas a una perspectiva premoderna y otra moderna, junto a la evaluación de su rendimiento explicativo tanto en teoría analítica del 
que responden a la observancia de ciertos objetivos que los agentes externamente le atribuyen para satisfacer. Lo jurídico se asocia a un proceso complejo de formulación en cuya virtud la intencionalidad colectiva del grupo social establece funciones a objetos que, en principio, no tienen condiciones internas que justifiquen desempeñarlas ${ }^{3}$. Mientras una comprensión pre-moderna de lo jurídico, afirma el carácter natural del derecho, la postura moderna lo reafirma como un artificio instrumentalmente creado ${ }^{4}$.

De modo que desde el punto de vista de una noción moderna de lo jurídico, una cuestión radica en justificar al derecho como una elaboración humana destinada a resolver un problema de cooperación y, a su vez, otra distinta exigiría evaluar la pertinencia del contrato, en tanto institución jurídica identificadora del sistema jurídico privado, para satisfacer tal propósito. Lo relevante, entonces, radica en disolver la aparente distinción entre dos órdenes de problemáticas; a saber, por un lado, preguntarse por la justificación de la existencia del contrato y, de otro, cuestionar la obligatoriedad del vínculo contractual. En lo que sigue, asumiré que ambas temáticas son en realidad una. Considero que es así, porque el tipo de conceptos, prácticas e instituciones que define al sistema jurídico, responde a juicios normativos y no meramente descriptivos. Prima facie, la justificación de la existencia del contrato no es un problema independiente de legitimar la obligatoriedad de su cumplimiento, ya que la institución contractual está pensada para alcanzar objetivos o satisfacer ciertos estándares de corrección que se estiman valiosos por la comunidad. Estos objetivos o estándares, que sirven de justificación para crear al contrato, son los mismos que sirven para exigir su cumplimiento 5 . De modo que cuando nos preguntamos por qué existe el contrato bajo el fenómeno jurídico

derecho como en filosofía del derecho privado, véase Pereira Fredes, Esteban (2014b). "Dos versiones sobre el fenómeno jurídico". Revista de Estudios de la Justicia, No 21 (en prensa).

${ }^{3}$ SeArle, John (1997). La construcción de la realidad social [The Construction of Social Reality]. Domènech, Antoni (Trad.), Barcelona: Paidós, pp. 49-74.

${ }^{4}$ Una imagen paradigmáticamente pre-moderna sobre el fenómeno jurídico, se encuentra en la teoría del derecho tomista, según la cual el derecho deriva de la estructura natural del mundo, revistiendo caracteres de inmutabilidad y corrección moral. Al respecto, véase TomÁs (2001). Suma de Teología, Tomo III, II-II (a). Regentes de Estudios de las Provincias Dominicanas en España (Trad.), Madrid: BAC, pp. 469-498. A su vez, el esquema hobbesiano otorga luces sobre la perspectiva moderna del derecho, bajo la cual lo jurídico es puesto por los individuos para resolver instrumentalmente el problema de inseguridad que los aqueja, al situarse en un estado de cosas donde no existe derecho, justicia ni moral. De modo que lo jurídico responde a dimensiones de contingencia y neutralidad normativa. HobBEs, Thomas (1992). Leviatán, o la materia, forma y poder de una república eclesiástica y civil [Leviathan, or The Matter, Form and Power of a Commonwealth, Ecclesiastical and Civil]. SÁnchez Sarto, Manuel (Trad.), México D.F.: Fondo de Cultura Económica, pp. 100-117.

${ }_{5}^{5}$ Este esquema es asumido por Peter Benson en su explicación acerca de los contratos. Desde su esquema de análisis, los principales esfuerzos teóricos sobre la comprensión de la institución contractual, constituyen aproximaciones conceptuales y metodológicas que polemizan sobre su legitimidad. Al respecto, véase Benson, Peter (2010). "Contract". En: A Companion to Philosophy of Law and Legal Theory. Oxford: Blackwell, pp. 29-63. 
privado, nos cuestionamos, en última instancia, por qué esta institución obliga a los contratantes de la forma como les obliga, es decir, incondicionadamente.

El problema de la fuerza vinculante del contrato precisamente busca dar cuenta de este dilema. Sostener que el vínculo contractual goza de fuerza vinculante no solo implica reconocer la vigencia de uno de los principios básicos de la contratación, sino también que luego de ponerse a prueba la justificación normativa del efecto obligatorio, hemos determinado una aproximación satisfactoria $y$, bajo tal consideración, la fuerza vinculante de la institución contractual deviene incontrovertible. Antes de ello, el reduccionismo a la legislación codificada solo nos puede brindar una razón parcial para cumplir una relación contractual, aun cuando existan razones meritorias para defraudarlo. Sencillamente porque dichas consideraciones se han desplazado en virtud de la existencia de la regla jurídica contractual. Esta estrategia traiciona el carácter normativo del fenómeno jurídico en general y al régimen contractual en particular, cuyas regulaciones responden a propósitos y expectativas sociales.

\subsection{El artículo 1545 del Código Civil y su reconocimiento jurídico}

El análisis del efecto obligatorio del contrato no puede desvincularse de la autonomía de la voluntad que fundamenta a la institución contractual. En efecto, uno de los principios de la contratación es la autonomía de la voluntad y, según se indica, la fuerza obligatoria del contrato es una derivación de aquella. A partir de la vigencia de la autonomía de la voluntad, entendida como piedra angular de las obligaciones jurídicas, los agentes pueden constituir voluntariamente relaciones contractuales, cuya obligatoriedad es incuestionada y jurídicamente respaldada ${ }^{6}$. Bajo el sistema jurídico privado chileno, el artículo 1545 del Código Civil consagra la fuerza obligatoria de los vínculos contractuales. Dicho texto normativo dispone lo siguiente: "[t]odo contrato legalmente celebrado es una ley para los contratantes”. Esta prescripción de nuestro codificador encuentra sus orígenes en el Código Civil napoleónico de 1804, cuyo inciso $1^{\circ}$ del artículo 1134, establece que "[l] os acuerdos legalmente formados tendrán fuerza legal entre quienes los hayan efectuado". De igual modo, se trata de una regla de genérica consagración bajo el contexto jurídico comparado? .

\footnotetext{
${ }^{6}$ Una lectura según la cual el efecto obligatorio del contrato constituye una consecuencia normativa del principio de autonomía de la voluntad, en Vial del Río, Víctor (2003). Teoría General del Acto Jurídico. Santiago: Editorial Jurídica de Chile, pp. 57-58.

${ }^{7}$ En el escenario comparado ha resultado indispensable la consagración de la fuerza obligatoria de los contratos, aun cuando esas estrategias difieren en la articulación de la regla. Es posible destacar las normativas peruana y argentina como expresiones del reciente proceso de codificación latinoamericano. Las reglas son las siguientes: (i) Código Civil Peruano [1984] Obligatoriedad de los contratos. Artículo 1361. "Los contratos son obligatorios en cuanto se haya expresado en ellos. Se presume que la declaración expresada en el contrato responde a la voluntad común de las partes y quien niegue esa coincidencia debe probarla". (ii) Código Civil Argentino [2014] Artículo 959. Efecto vinculante. "Todo contrato válidamente celebrado
} 
Al regir la autonomía de la voluntad en nuestras relaciones jurídicas privadas, es una consecuencia necesaria afirmar categóricamente la obligatoriedad de tal vinculación construida entre personas determinadas. La intensidad de esta consideración se devela a partir de dos grupos de consideraciones. Por una parte, el significado del aforismo pacta sunt servanda y, por otra, la analogía que señala nuestro legislador existe entre el contrato y la ley. En relación al significado de la expresión pacta sunt servanda, esta exige que "[...] los pactos deben observarse; las palabras deben cumplirse; los contratos obligan". Pero la intensidad de estos términos se refleja en la comprensión que Thomas HоBBES sostuvo sobre el pacta sunt servanda, para quien constituye una de las leyes de la naturaleza que sirven de parámetro normativo para las acciones de los individuos.

Para el autor oxoniense la tercera ley de la naturaleza es la siguiente: "[q] ue los hombres cumplan los pactos que han celebrado" . La relevancia de esta regla radica en que si aquella no existiere, los pactos serían vanos y solo contendrían meras palabras vacías. De este modo que habría derecho de todos los individuos a todo, posibilitándose el estado de guerra de todos contra todos. Desde luego, la razón que justifica al artículo 1545 del Código Civil no está asociada a prevenir un conflicto de la índole respecto a la cual HoBBEs nos ilustraba con su situación imaginaria de la condición humana natural. Pero sí se clarifica al momento de examinar lo que dicha ley origina; a saber, la justicia. Para HOBBES, si no media pacto, no se ha transferido derecho alguno, correspondiéndole a todos los agentes derecho a todo porque ninguna acción podría evaluarse como injusta. No existe criterio de corrección moral. Sin embargo, al existir un pacto, su rompimiento deviene injusto. En sus términos: "[1] a definición de injusticia no es otra sino ésta: el incumplimiento de un pacto. En consecuencia, lo que no es injusto es justo" ${ }^{10}$. La justicia se asocia al cumplimiento de nuestros pactos y, a su vez, la injusticia se identifica con su transgresión. Goza de corrección moral que el sistema jurídico privado exija la observancia de los compromisos voluntarios de los partícipes de la práctica contractual.

Como sabemos, en HobBes no es posible hablar de justicia y propiedad sin la existencia del Estado, porque la voluntad del soberano se manifiesta en la legislación y, de ahí, cobran sentido las dicotomías lingüísticas como "correcto" e "incorrecto", “justo” e "injusto”, así como "tuyo” y "mío”. El sistema jurídico moderno considera deseable el cumplimiento de las estipulaciones contractuales

\footnotetext{
es obligatorio para las partes. Su contenido sólo puede ser modificado o extinguido por acuerdo de partes o en los supuestos en que la ley lo prevé”. En tanto, una articulación clásica europea se encuentra en la legislación civil española. Ahí se dispone lo siguiente: Código Civil Español [1889] De la eficacia de los contratos. Artículo 1278. "Los contratos serán obligatorios, cualquiera que sea la forma en que se hayan celebrado, siempre que en ellos concurran las condiciones esenciales para su validez".

${ }^{8}$ López Santa María, Jorge (2010). Los Contratos. Parte General. Santiago: Editorial Jurídica de Chile, p. 223.

${ }^{9}$ Hobbes (1992), p. 118. Cursivas del original.

${ }^{10}$ Hobbes (1992), p. 118. Cursivas del original.
} 
y, bajo esta observación, los contratantes gozan de derechos subjetivos para exigir forzosa e institucionalmente el cumplimiento de aquello que hayan pactado. Se requiere del poder político para formular efectivamente un régimen contractual, otorgando luces sobre el sentido de la asimilación de un contrato legalmente celebrado a la formulación de una legislación para sus contratantes. El autor de Leviatán deja patente esta necesidad, pues "[...] debe existir un poder coercitivo que compela a los hombres, igualmente, al cumplimiento de sus pactos, por el temor de algún castigo más grande que el beneficio que esperan del quebrantamiento de su compromiso [...]"11.

En relación a la asimilación que efectúa nuestro codificador entre el contrato y la ley, conviene detenerse a transparentar el sentido de la estrategia de Bello. Mientras el Code prescribe que los acuerdos legalmente celebrados tendrán fuerza de ley entre los contratantes, el Código Civil de 1855 indica que un contrato legalmente celebrado constituye una ley para sus contratantes ${ }^{12}$. La técnica del texto napoleónico es más precisa en demarcar entre dos cuestiones distintas, es decir, la identidad y los efectos de ambas instituciones, contrato y ley. Si hablamos de identidad, es indudable que contrato y ley responden a identidades contrapuestas. Así, por ejemplo, mientras la ley vale porque la voluntad del pueblo lo ha determinado de este modo, y manda prohíbe o permite porque así lo ha establecido la comunidad que se gobierna, el contrato responde a un acuerdo de voluntades para generar vínculos obligacionales que responden a los intereses de las partes y el sistema jurídico los autoriza. La ley tiene aplicación normativa general respecto a todos los habitantes de la República y el contrato solo surte efectos respecto de quienes concurrieron personal o de manera representada a su formación. Si las reglas legales no se encuentran bajo la disposición o derogación de los particulares, las reglas contractuales admiten ser creadas y suprimidas según la voluntad de los intervinientes en la relación privada. Finalmente, si bien tanto la interpretación de la ley como la contractual se encuentran regladas, la búsqueda del sentido de una ley se rige por los artículos 19 a 24 del Código Civil y, en tanto, la interpretación de una estipulación contractual se encuentra reglamentada entre los artículos 1560 a 1566 del Código de Bello. Dichas interpretaciones son sustancialmente diferentes por cuanto unas miran al interés colectivo y, en tanto, las otras atienden al interés de las partes contratantes.

\footnotetext{
11 Hobbes (1992), p. 118.

${ }^{12}$ En relación a la estrecha relación que existe entre las definiciones del contrato consagradas en el Código Civil y en el texto del codificador francés, véase Corral Talciani, Hernán (2002). "La definición del contrato en el Código Civil chileno y su recepción doctrinal. Comparación con el sistema francés”. En: Cuadernos de Extensión Jurídica, № 6, pp. 69-97. Una reconstrucción histórica respecto a la errónea interpretación que habría adoptado la dogmática civil nacional sobre las fuentes intelectuales del artículo 1545 del Código Civil, a la luz del dogma de la autonomía de la voluntad, se encuentra en PiZArRo WiLson, Carlos (2004). "Notas críticas sobre el fundamento de la fuerza obligatoria del contrato. Fuentes e interpretación del artículo 1545 del Código Civil chileno". Revista Chilena de Derecho, Vol. 31, No 2, pp. 225-237.
} 
De modo que la estrategia de Bello de conectar a la ley con el contrato no radica en establecer una equivalencia conceptual entre ambas instituciones, ya que sus identidades son radicalmente diferenciadas. El propósito de nuestro cuerpo legal es el mismo que tuvo en mente el codificador francés y antes la jurisprudencia romana, es decir, expresar a la fuerza obligatoria de la relación contractual. De igual manera que la asimilación entre la culpa grave y el dolo consagrada en el artículo 44 inciso $2^{\circ}$, de nuestro Código, que radica en una asimilación estricta, circunscrita únicamente a los efectos de la reparación contractual, amplificando la carga reparatoria del deudor, la asimilación sugerida por el artículo 1545 es solo metafórica e instrumental. Es metafórica porque no busca identificar conceptualmente al contrato con la ley y, asimismo, se ajusta a una racionalidad instrumental, porque mediante esa analogía se devela aquello que ambas instituciones comparten; a saber, que la forma, de acuerdo a la cual las normas legales y contractuales, obligan a sus respectivos destinatarios es absoluta y, en principio, incondicionada.

$\mathrm{Al}$ respecto, Luis Claro Solar suscribe esta funcionalidad de relacionar normativamente a la ley con el contrato:

"La comparación del contrato con la ley en cuanto al efecto que está llamado a producir entre los contratantes es tradicional. El jurisconsulto romano quiere indicar una idea exacta y completa de la fuerza obligatoria del contrato; y no encuentra una palabra más apropiada para expresarla que decir que el contrato constituye una ley, legem contractus dedit [...] Y el legislador moderno no podía dejar a un lado una fórmula que con tanta exactitud expresaba el efecto obligatorio del contrato" 13 .

Pues bien, ¿cuáles consecuencias jurídicas se siguen del pacta sunt servanda en nuestro sistema jurídico privado? De forma estándar se sostiene que "[1]a obligatoriedad del contrato se traduce en su intangibilidad" ${ }^{4}$. Un contrato celebrado con observancia de la legislación vigente deviene en cuanto a su obligatoriedad en una ley y, por consiguiente, no puede ser tocado o modificado. Dicho alcance de inmutabilidad resulta operativo en tres ámbitos. En primer lugar, vincula a las partes contratantes a cumplir el contrato según los términos pactados, aun cuando les resulte perjudicial. En segundo lugar, vincula al legislador quien se encuentra impedido de vulnerar el efecto obligatorio del vínculo contractual. Y, en tercer lugar, obliga al juez que pudiere conocer del contrato para resolver una controversia judicial suscitada, a no revisar ni modificar las estipulaciones contractuales vigentes. Sin embargo, las pretensiones de intangibilidad se interrumpen en la realidad contractual respecto a estas dos últimas esferas de aplicación. En sede legislativa se transgrede la fuerza del artículo 1545 del texto de Bello mediante la dictación de leyes de emergencia, leyes permanentes que alteran los alcances

13 Claro Solar, Luis (1935). Explicaciones de Derecho Civil Chileno y Comparado. Tomo IX. Santiago: Nascimento, p. 470.

${ }^{14}$ López Santa María (2010), p. 235. 
de las reglas contractuales y leyes modificadoras sobre materias contractuales con efecto retroactivo. En tanto, bajo el contexto judicial la teoría de la imprevisión ha ofrecido dificultades a la intangibilidad de un contrato legalmente celebrado. Existen hipótesis, se piensa, en que el cambio sobreviniente de las circunstancias vigentes al momento de la contratación, autorizaría al juez a revisar las estipulaciones contractuales o bien a declarar judicialmente la resolución del contrato ${ }^{15}$.

La vigencia de la fuerza obligatoria del vínculo contractual deviene incontrovertible si apelamos únicamente a la existencia de la regla contractual que lo sostiene. En principio, se puede argumentar que bajo nuestro sistema jurídico privado el incumplimiento de una relación contractual es incondicionado del mismo modo en que las leyes sujetan a los agentes a su observancia, porque así lo prescribe la regla contenida en el artículo 1545 del Código Civil. Dicha fuerza obligatoria sería excluyente para los contratantes ya que la regla contractual, como toda regla jurídica, puede ser una razón excluyente para las acciones de los individuos. Joseph RAz ha observado que existe una tipología de razones que pueden justifican por qué un agente realiza la acción que efectúa ${ }^{16}$. Existen razones de primer orden para seguir un curso de acción, pero que admiten ser tematizadas por los agentes, dado que pueden cuestionarse a la luz de otras razones de primer orden. La solución frente a un conflicto de razones de primer orden se adjudicará según el criterio denominado de balance: la razón de primer orden más fuerte vencerá a la que se estime como débil ${ }^{17}$. Sin embargo, también participan razones de segundo orden, como las razones excluyentes, a partir de las cuales se ofrecen razones a los agentes para desplegar sus acciones, esgrimiendo una razón para abstenerse de evaluar el mérito de otras razones. El balance acá no resulta operativo, porque la razón excluyente precisamente desplaza la pertinencia de toda consideración que pudiere superar a la razón para desarrollar la acción. Un razonamiento exclusionario exige desplazar a las razones contradictorias a la razón de segundo orden. De ahí que "[e]n tales conflictos prevalece siempre la razón excluyente" ${ }^{18}$.

En este sentido, piensa RaZ, la identidad de las normas de mandatos debiere ajustarse a razones de segundo orden. Las reglas jurídicas constituyen razones ex-

\footnotetext{
${ }^{15}$ Sobre la teoría de la imprevisión y la revisión judicial de los contratos, puede consultarse BARCIA LEHMANN, Rodrigo (2005). “¿Es posible construir la teoría general del contrato desde la excepción: la revisión judicial del contrato?”. En: Sesquicentenario del Código Civil de Andrés Bello: Pasado, Presente y Futuro de la Codificación, Tomo I. Santiago: LexisNexis, pp. 685-719 y Pereira Fredes, Esteban (2009). "Sobre la teoría de la imprevisión”. La Razón del Derecho. Revista Interdisciplinaria de Ciencias Jurídicas, No 1, pp. 1-20. Acerca de su necesaria reglamentación bajo nuestro sistema jurídico privado, véase MOMBERG URIBE, Rodrigo (2010). "Teoría de la imprevisión: la necesidad de su urgente revisión en Chile". Revista Chilena de Derecho Privado, No 15, pp. 29-64.

${ }^{16}$ Raz, Joseph (1991). Razón práctica y normas [Practical Reason and Norms]. Ruíz Manero, Juan (Trad.), Madrid: Centro de Estudios Constitucionales, pp. 17-54.

17 Raz (1991), p. 51.

${ }^{18}$ Raz (1991), p. 52.
}

Revista de Derecho · Escuela de Postgrado No 6, diciembre 2014 
cluyentes para la acción de sus destinatarios ${ }^{19}$. Si esto fuere así, es posible descartar el debate en torno a la razonabilidad normativa o la conveniencia práctica de seguir la regla contractual establecida por Bello, porque dicha regla jurídica nos entrega dos razones de diferente especie. De un lado, una razón de primer orden, que insta a los contratantes a cumplir sus acuerdos del mismo modo en que ocurre respecto a la legislación y, de otro, una razón de segundo orden, en virtud de la cual se ofrece una razón para abstenerse de evaluar la corrección de la razón que obliga a cumplir el contrato, impidiendo ponderar su mérito frente a razones contradictorias, como aquellas consideraciones relativas al incumplimiento del vínculo contractual. De este modo operaría el razonamiento práctico de los sujetos del derecho; a saber, excluyendo razones y aceptando la clausura de consideraciones válidas que supone el carácter autoritario del fenómeno jurídico.

Sin embargo, si no se estima como suficiente la explicación que reduce la fuerza obligatoria del contrato a la presencia del artículo 1545 bajo el Código Civil, en atención a que su identidad constituye una razón excluyente para asegurar el cumplimiento del pacto para los contratantes, entonces, la discusión se sitúa en el marco del problema sobre la justificación de la obligatoriedad del contrato. Es decir, resulta menester presentar y evaluar de manera crítica los criterios normativos y argumentos conforme a los cuales se legitima la existencia de una regla jurídica contractual, prescrita en los términos de la regla jurídica que contempla el sistema jurídico privado nacional. La pregunta que motiva el presente trabajo no radica en poner a prueba la existencia de la fuerza obligatoria del contrato, relativo a un primer orden de consideraciones en la dogmática civil, el desafío más bien es uno de segundo orden. El propósito es reflexionar críticamente sobre en qué sentidos es justificable la existencia de nuestra regla contractual y, enseguida, evaluar la pertinencia de esas consideraciones bajo nuestro sistema jurídico privado. En el próximo apartado se presentarán las estrategias de mayor influencia para dar cuenta del problema sobre la fundamentación de la obligatoriedad de la relación contractual ${ }^{20}$.

\subsection{Alternativas conceptuales de comprensión}

Si el problema de la fuerza obligatoria del contrato no consiste en interpretar formalmente los términos de la regla contractual vigente en nuestra legislación, sino en examinar las aproximaciones teóricas de acuerdo a las cuales se puede tematizar la pertinencia de la regla en un sistema jurídico privado, es posible reconducir tales intentos conceptuales a los siguientes grupos de consideraciones:

\footnotetext{
19 RAZ (1991), pp. 39-54.

${ }^{20}$ Brian Bix recientemente ha sugerido que el estudio de las prácticas del derecho contractual moderno, versa sobre cuestiones de legitimación y preocupaciones sobre nuestras obligaciones morales de mantener la vigencia del contrato, así como dar cuenta de las distintas formas en que el gobierno debiere regular a las prácticas contractuales. Al respecto, véase BIX, Brian H. (2012). Contract Law. Rules, Theory, and Context. Cambridge: Cambridge University Press, pp. 128-146.
} 
(i) Esquemas normativos

(ii) Esquemas no-normativos

Bajo el contexto contemporáneo de (i) encontramos las estrategias utilitaristas, neoaristotélicas y aquellas asociadas a la relevancia de la autonomía de la voluntad y las promesas morales efectuadas por los contratantes. Estos esquemas comparten la tesis según la cual la justificación de la fuerza obligatoria del vínculo contractual, necesariamente debe establecerse a partir de observaciones evaluativas y no meramente descriptivas. No basta con explicar que los contratos obligan a quienes los generan gracias a su potestad normativa privada, sino que se requiere justificar por qué valorativamente es deseable la existencia y los términos del efecto vinculante del contrato. La justificación requiere de un lenguaje moral porque apela a la aceptabilidad de estos criterios. Entonces, la discrepancia de tales modelos de comprensión se expresa en el contenido e identidad de los criterios de corrección moral que aquellos emplean en su articulación. Si bien el diagnóstico es común, la discrepancia se decanta en las conclusiones contrapuestas a las cuales arriban.

En cambio, las propuestas que conforman la serie de (ii) se distancian de las tesis normativas en el punto central en discusión, esto es, aceptar la necesidad de adoptar la regla contractual bajo consideraciones morales. Su propuesta radica en fracturar la obligatoriedad del contrato de criterios evaluativos. Así, resultan pertinentes alegaciones económicas de eficiencia, que incluso pueden quebrar el cumplimiento incondicionado de la relación contractual. Como criterios lógicojurídicos asociados a las condiciones de imputabilidad de consecuencias jurídicas, a partir de la verificación de supuestos factuales como condición de operatividad de reglas jurídicas, entendiendo que la celebración de un contrato constituye el hecho operativo. Nuevamente, ambas tesis coinciden en el rechazo al carácter normativo que identifica a (i), pero problematizan de manera distinta sobre cómo hacer frente a la fuerza obligatoria derivada de la regla contractual.

\subsubsection{Esquemas normativos de justificación}

\subsubsection{El utilitarismo y las consecuencias contractuales}

El utilitarismo es una posición en filosofía moral asociada a los planteamientos de Jeremy Bentham y John Stuart Mill sostenidos entre los siglos XVIII y XIX. El utilitarismo, según lo entiende Mill, acepta como fundamento de la moralidad al criterio de la utilidad o principio de la mayor felicidad. De modo que "[...] las acciones son correctas (right) en la medida en que tienden a promover la felicidad, incorrectas (wrong) en cuanto tienden a producir lo contrario a la felicidad" 21 . Mientras la felicidad se asocia a presencia de placer y ausencia de dolor, la infelicidad consiste en el dolor e inexistencia de placer.

${ }^{21}$ Mill, John Stuart (2007). El Utilitarismo [Utilitarianism]. Guısán, Esperanza (Trad.), Madrid: Alianza, pp. 49-50. Cursivas del original. 
El utilitarismo milleano formuló ciertos correctivos a algunos puntos de la propuesta benthamita, que fueron objeto de severas objeciones en la historia de la reflexión moral. Por una parte, al erigir a la felicidad como criterio de corrección normativa para evaluar a nuestras acciones, no se alude a la felicidad del propio agente moral cuyo comportamiento se juzga, sino que se preocupa de la felicidad general, es decir, de promover el placer y la evitación del dolor del conjunto de la comunidad. Por otra parte, a diferencia de las doctrinas epicúreas, el enfoque utilitarista de Mill esgrime un criterio cualitativo de los placeres, desplazando al mero criterio cuantitativo para adjudicar la corrección de una conducta. No solo importa la cantidad de los placeres que la acción reporte a los seres humanos. El acento de la evaluación moral se sitúa en la calidad de los placeres. En particular, como lo indica el autor de El Utilitarismo, los utilitaristas, "[...] han basado la superioridad de los placeres mentales sobre los corporales" ${ }^{22}$. Es decir, la disputa entre bienes o placeres contrapuestos cede a favor de la sustancia en desmedro de la mayor cuantificación que puedan llegar a disfrutar el grupo genérico de agentes.

Desde la propuesta utilitarista, la justicia se conecta con la utilidad. La conducta calificada como útil a la sociedad debe considerarse, por dicha estimación, como justa. Después de todo, el principio de utilidad es un criterio de corrección moral para esta doctrina sobre ética normativa. Sobre la pertinencia de evaluar normativamente la fuerza vinculante de los acuerdos, se afirma que "[...] resulta injusto tal como se confiesa abiertamente, faltar a la palabra dada a alguien: violar un compromiso ya explícito o implícito, no satisfacer las expectativas creadas por nuestra propia conducta, al menos si nosotros hemos creado esas expectativas consciente y voluntariamente"23. Lo justo se determina por su consistencia con la utilidad social. Existen conductas que contribuyen al bienestar social y comportamientos que defraudan las expectativas sociales de felicidad. De ahí que el cumplimiento de los contratos sería correcto, porque contribuye a aumentar la felicidad general y el incumplimiento de la relación contractual se evalúa como incorrecto porque no le reporta utilidad alguna a la humanidad. Pocas cosas provocan más dolor a los seres humanos que fracturar la confianza que ellos han depositado en otros agentes. Esta vulneración a las expectativas "[...] constituye la principal malicia de dos actos en gran medida inmorales como lo son el defraudar al amigo o el incumplir una promesa" ${ }^{24}$. Transgredir nuestros pactos solo genera desconfianza a la comunidad respecto a la práctica contractual, resultando una conducta incorrecta por carecer de utilidad social ${ }^{25}$.

22 Mill (2007), p. 51.

${ }^{23}$ Mill (2007), p. 110. Cursivas del original.

${ }^{24}$ Mill (2007), p. 133.

${ }^{25}$ Desde luego, esta presentación de la doctrina utilitarista podría ponerse a prueba a la luz de la distinción entre el utilitarismo de reglas y utilitarismo de actos. Al respecto, véase SMART, J. C. C. (1974). "Utilitarismo 
John RAWLS, para distinguir entre la justificación de la práctica y la justificación de la acción que recae dentro de aquella, ha examinado la aparente incompatibilidad explicativa entre las posiciones utilitaristas y retributivas sobre la justificación del castigo, así como respecto a la obligación de cumplir las promesas ${ }^{26}$. De manera preliminar, utilitarismo y retribucionismo ofrecen argumentaciones contradictorias respecto a la obligatoriedad de las promesas porque justificar su obligatoriedad en relación a las futuras consecuencias beneficiosas que acarrea el cumplimiento, es opuesto a legitimar su vinculación mirando hacia el pasado, sugiriendo que quien promete debe cumplir lo pactado porque se comprometió a hacerlo. Su distinción lógica permite disolver la anterior dicotomía explicativa, situando la justificación utilitarista en la práctica contractual definida por el legislador al dictar la regla jurídica que consagra la fuerza vinculante del contrato, y ubicar la aproximación retributiva en la justificación de la aplicación de la regla contractual, desplegada por el juez al momento de forzar a un contratante a cumplir la promesa que antes ha formulado, toda vez que efectivamente se comprometió a observarla. Si los ámbitos de competencia legislativa y judicial son distintos, también responden a justificaciones diferenciadas. Dicha demarcación se proyecta tanto a la justificación del castigo como a la obligatoriedad de las promesas, en la medida que el punto de vista consecuencialista será pertinente al momento de establecer la regla contractual y, en tanto, la sensibilidad retributiva tendrá vigencia cuando se efectúe la acción de aplicar dicha regla bajo el marco de la práctica contractual.

RAWLS nos indica que el principio utilitarista afirma que "[...] cuando alguien hace una promesa, el único fundamento por el que ha de cumplirla, si la ha de cumplir, es que ajustándose a ella cooperará al mejor bien de todos”27. De ahí que podría objetarse que existe una tensión en la propuesta utilitarista sobre la obligatoriedad de las promesas, dado que gracias a la observancia de la promesa de un agente particular se obtendrían las mejores consecuencias para todos. Perfectamente, el promitente en cuestión podría cuestionar los postulados de esta doctrina, y considerar que incumplir su promesa no necesariamente provoca consecuencias indeseadas para la comunidad en general. No obstante, la distinción entre justificar una práctica y una acción verificada en su interior diluye esta objeción. Es posible apelar al principio utilitarista para justificar la práctica de las promesas y los contratos, sin que por ello el contratante pueda emplear con libertad argumentaciones de corte consecuencialista para decidir si cumple o incumple una promesa. Estar situado bajo la práctica contractual impide que el agente pueda evaluar la corrección de la conexión entre cumplimiento, justicia y utilidad social. Más bien,

extremo y restringido" [Extreme and Restricted Utilitarianism]. En: Teorías sobre la Ética. Arboli, Manuel (Trad.), México D.F.: Fondo de Cultura Económica, pp. 248-265.

${ }^{26}$ RaWls, John (1974). "Dos conceptos de reglas" [Two Concepts of Rules]. En: Teorías sobre la Ética. Arboli, Manuel (Trad.), México D.F.: Fondo de Cultura Económica, pp. 210-211.

${ }^{27}$ RaWls (1974), p. 223. 
“[...] el prometiente está obligado porque prometió; no depende de él juzgar el caso según lo merezca” 28 .

\subsubsection{El contrato y su tradición aristotélica}

La generosa herencia intelectual del Estagirita se refleja con propiedad en la justificación de la fuerza obligatoria del contrato. Sabemos que observar un vínculo contractual es justo, en la medida que se entiende como un acto virtuoso. La ética aristotélica constituye una postura teleológica que asocia lo bueno con el ejercicio constante de una virtud en sus distintas prácticas. La justicia constituye la virtud de mayor relevancia en el catálogo de virtudes, en efecto, "[e]s la virtud en el más cabal sentido, porque es la práctica de la virtud perfecta, y es perfecta, porque el que la posee puede hacer uso de la virtud con los otros y no sólo consigo mismo"29.Aquel contratante que en sus relaciones contractuales observa lo que voluntariamente ha pactado, despliega una vida buena porque ejerce una virtud que es la justicia y así encaminará su actuar hacia la felicidad, admitida como el bien más excelso al cual la vida humana puede aspirar. El problema en ARISTÓTELES no radica en determinar si un agente debe o no cumplir un contrato que celebra, pues de su carácter virtuoso se sigue su necesidad, sino que lo relevante es determinar a qué tipo de exigencias de justicia responde la fuerza obligatoria del vínculo contractual.

$\mathrm{Al}$ respecto, la distinción central sobre la justicia establecida por ARISTÓTELES diferencia entre la justicia conmutativa y la justicia distributiva. Esta última se encuentra asociada a una distribución de los bienes y las cargas desde un contexto de subordinación, entre el todo y las partes, en cuya virtud lo justo se vincula a una proporción que es geométrica. La proporción se articula en base a una igualdad de razones respecto a cuatro términos y esa proporción es justa. De forma geométrica, el todo se encuentra, respecto al todo, bajo la misma relación que cada parte respecto de cada parte. Según ARISTÓTELES, "[l]o justo, entonces, es la proporción, y lo injusto lo que va contra la proporción" ${ }^{30}$.

En cambio, la justicia conmutativa es aquella especie de justicia que "[...] tiene lugar en los tratos mutuos, tanto voluntarios como involuntarios”31. Bajo el gobierno de la justicia correctiva, hablamos de relaciones entre individuos que se encuentran en una posición de coordinación o mutua reciprocidad. De ahí que la justicia conmutativa no se ajusta a exigencias geométricas de proporción, sino a una igualdad entre los particulares. De manera que "[...] lo justo es, sin duda, una igualdad y lo injusto una desigualdad" 32 . Pero tal esquema de justicia respon-

\footnotetext{
${ }^{28}$ RAWLS (1974), p. 227.

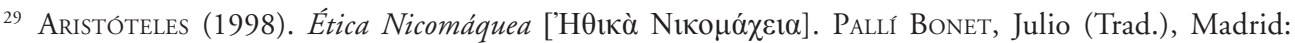
Gredos, p. 239.

30 Aristóteles (1998), p. 245.

31 Aristóteles (1998), p. 245.

32 Aristóteles (1998), p. 245.
} 
de a una proporción aritmética. Como se podrá apreciar, para el contexto de la contratación, la obligatoriedad del cumplimiento de los pactos entre particulares se conforma a los criterios de la justicia conmutativa.

En los intercambios voluntarios cobran relevancia las nociones de ganancia y pérdida, porque los negociantes se sitúan bajo una relación de equilibrio, propia de la aspiración germinal del derecho de los contratos, y todo posible daño provocado por un negociante hacia su contratante implica una ganancia ilegítima al primero y, a su vez, una pérdida injusta al segundo. Si hablamos de un incumplimiento contractual, el contratante negligente reportará una ganancia y su víctima contractual sufrirá una pérdida relativa al daño que la transgresión del pacto le haya generado. De modo que el restablecimiento de la justicia le compete al juez, pudiendo únicamente lograrse devolviendo el monto que identifica a la ganancia y pérdida, a quien lo ha perdido, fracturando el equilibrio original del intercambio. Su actividad aspirará a recomponer el término medio entre la ganancia y la pérdida, pues la justicia constituye un término medio entre lo más y lo menos. En el marco contractual, el comportamiento diligente del contratante que cumple es virtuoso, ya que ratifica la igualdad en el cambio voluntario y, por su parte, quien incumple un contrato defrauda la virtud más excelsa, esto es, la justicia en su esfera correctiva que rige la vida contractual. Gracias al juez se rectifica el sobrevenido desequilibrio, en la medida que habrá justicia cuando "[...] dos partes no tienen ni más ni menos sino lo mismo que tenían [...]", su relación será nuevamente justa porque los contratantes "[...] tienen lo que pertenece a cada uno y que ni pierden ni ganan" 33 .

Los planteamientos aristotélicos informaron sustantivamente la filosofía del Aquinate. TOMÁs DE AQUino recepcionó la distinción entre ambos tipos de justicia y también identificó a la justicia conmutativa, ahora también correctiva, como aquella que tiene lugar en los intercambios privados. La relación de igualdad se garantiza pues "[...] cuando uno tiene más de lo que le corresponde, y ese exceso pertenece al otro, tenga que restituirlo a su dueño"34. La proporción se genera respecto al objeto que se trata, de modo que si al principio ambos contratantes tenían diez y como resultado de la conmutación uno queda con nueve y el otro con once, las exigencias de la justicia reclaman que el segundo debe dar uno al primero para que vuelva a tener vigencia el punto medio, situación que ocurrirá una vez que ambas partes tengan diez.

A diferencia de Aristóteles, Tomás conecta conceptualmente a las buenas acciones con el origen divino de las fuentes de normatividad. Es decir, tanto las reglas morales como las jurídicas se justifican, en última instancia, por su derivación racional de las normas cuya fuente radica en Dios. Las reglas jurídicas constituyen pautas de corrección moral, porque conducen a los agentes hacia el bien, por ende,

\footnotetext{
33 Aristóteles (1998), p. 247.

${ }^{34}$ Tomás III, II-II (a) (2001), p. 148.
} 
a alcanzar la contemplación de Dios. Actuar correctamente es comportarse según las normas que guían a la criatura racional hacia su Creador. Por consiguiente, una acción contraria a la razón divina es pecaminosa porque distancia a la criatura al encuentro con su Dios. La filosofía tomista centra la infracción a las normas de comportamiento en el castigo, procurando corregir la conducta de sus destinatarios. Esta noción genérica de castigo tiene proyección incluso en las conmutaciones a partir de las cuales ambos contratantes dan y reciben algo. De ahí que una regla contractual que consagre el efecto obligatorio del vínculo contractual se justifica en satisfacer las aspiraciones que la justicia correctiva interpela a todo el escenario de los intercambios privados. Desde TOMÁs, la regla contractual contenida en el artículo 1545 del Código Civil constituye una regla moral de equidad. Luego, se exige que "[...] si a alguno se le quita algo, se le recompense dándose lo mismo" 35 . Solo de esa forma se reconstruye la igualdad germinal y así tiene sentido hablar de justicia conmutativa en el orden contractual.

Un aspecto de significativo interés radica en analizar qué ocurriría si no existiere la regla contractual que establece la fuerza obligatoria del contrato. Bajo el contexto de la tipología de leyes del Aquinate, conviene detenerse en las relaciones existentes entre la ley natural y la ley humana. Estas relaciones se traducen a dos: derivación y concordancia. La ley humana para tener fuerza de ley debe derivar de la ley natural, ya sea por conclusión mediante un razonamiento silogístico, o bien por determinación. Esta última supone que junto a la derivación deductiva existen zonas de arbitrariedad para el gobernante que formula la ley humana. Dichas zonas no son relevantes porque resultan indiferentes para la recta razón divina. Asimismo, la ley humana debe concordar con la ley natural. A partir del axioma agustiniano según el cual "[...] la ley que no es justa no parece que sea ley”, TOMÁs entiende que ley humana que transgrede la justicia, no constituye ley sino una corrupción de ley ${ }^{36}$. La justicia se sigue de su equivalencia a la rectitud normativa, de manera de reducir el problema de la existencia de la regla en su contenido. Una norma humana válidamente promulgada, carece de fuerza de ley si su contenido no se ajusta a los principios de la ley natural. Como sabemos, el primer principio de la ley natural exige a la criatura hacer el bien y evitar el mal. Si cumplir los contratos pactados importa una acción justa al satisfacer la igualdad, transgredir el vínculo contractual conlleva una acción injusta que rompe dicha igualdad. Bajo estas consideraciones, no podría no existir una regla jurídica que consagre el efecto obligatorio del contrato, porque su existencia como regla jurídica válida se resuelve en exigencias de justicia en las conmutaciones entre las personas.

Desde el escenario contemporáneo, James GORDLEY ha reconstruido los fundamentos del derecho privado a la luz de la tradición aristotélica que pretende

\footnotetext{
35 Tomás III, II-II (a) (2001), p. 152.

36 Tomás II, I-II (2001), p. 742. Cursivas del original.
} 
implementar en las preocupaciones centrales de la filosofía del derecho privado; a saber, propiedad, daños, contratos y enriquecimiento injustificado ${ }^{37}$. El punto central radica en sostener que existe una vida distintivamente humana que las capacidades y habilidades contribuyen a desplegar ${ }^{38}$. De modo que todas las acciones que un agente efectúa constituyen medios para alcanzar dicha vida, siendo razonables aquellas acciones que contribuyen a alcanzar tal vida humana, y deficientes en razón aquellas que dificultan la obtención de ese estado virtuoso de cosas. Los seres humanos, a diferencia de los animales, cuentan con la habilidad de la prudencia para lograr identificar el tipo de conductas que se encuentran conformes a tal plan de vida, así como rechazar los comportamientos que la defrauden. Esta capacidad nos permite comprender lo que somos y, además, determinar con propiedad cuál decisión es razonable efectuar y cuál se presenta como no razonable de adoptar. Si bien las circunstancias particulares son relevantes, en la práctica los seres humanos cuentan con esa facultad para discernir entre cursos de acción mejores que otros cursos de acción.

No obstante, la vida buena no se conforma con el ejercicio de virtudes personales como la prudencia, templanza y valentía, "[...] porque la vida humana es social, y una persona no solo debe querer estas cosas para sí mismo, ya que también quiere ayudar a otros a adquirirlas" 39 . De manera que resulta necesario recuperar la distinción entre justicia distributiva y conmutativa. Mientras el propósito de la primera radica en asegurar que cada persona tenga los recursos que requiere, la finalidad de la justicia conmutativa se expresa en la medida que el agente pueda obtener los recursos sin disminuir de forma injusta la capacidad de los demás a obtenerla. Piensa Gordley, que el programa del neoaristotelismo se devela en términos de entrelazar el sentido plausible en que ambos sentidos de la justicia se formularon por ARISTÓTELES. De ahí que se considere “[...] bueno conservar parte de los recursos de cada persona porque es bueno que cada persona tenga lo que necesita para vivir como debe hacerlo. Uno puede hablar de cómo una persona debe vivir porque hay una vida propiamente humana de ser vivida y además una capacidad distintivamente humana de comprender y elegir lo que contribuye a una

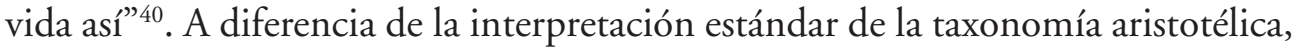
su comprensión contemporánea recalca la posibilidad de conciliar ambas identidades de la justicia, admitiendo que se trata de una virtud social expresada bajo

\footnotetext{
${ }^{37}$ Una posición de unidad asociada a la expectativa de formular un tratamiento relativamente uniforme a las distintas reglas jurídicas contractuales, recogiéndolas a partir de sus exigencias de moralidad en una gran teoría contractual, también ha sido sugerida en Bix, Brian H. (2008). "Contract rights and remedies, and the divergence between law and morality". Ratio Juris, Vol. 21, No 2, pp. 194-211.

${ }^{38}$ Gordley, James (2006). Foundations of Private Law. Property, tort, contract, unjust enrichment. Oxford: Oxford University Press, p. 7.

39 Gordley (2006), p. 8.

${ }^{40}$ Gordley (2006), p. 8.
} 
dos dimensiones, de igual modo conducentes hacia la vida genuinamente humana. Evitar el divorcio de ambas exigencias de la justicia conlleva un desafío necesario de afrontar para la teoría del derecho privado, en atención a las consecuencias que se producirían en el examen de las reglas sobre contratos, responsabilidad extracontractual y enriquecimiento injustificado.

En particular, estas observaciones se ubican bajo dos dimensiones de análisis. Por una parte, se clarifica que al momento de definir las reglas jurídicas sobre aquellas tres preocupaciones no se pueden soslayar las exigencias de justicia distributiva, es decir, descuidando el efecto que las normas pueden tener en la distribución de los recursos entre los agentes. Y, en sede contractual, este parámetro normativo procura que en los intercambios voluntarios nadie se enriquezca a expensas del otro $^{41}$. Si existe un daño que reparar en materia contractual, este se manifiesta en que el contratante que ha incumplido su pacto se enriquece a expensas del negociante diligente. Si ha mediado esta infracción, quien se ha enriquecido a partir del intercambio debe restituir aquello que refleja el daño contractual. Por otra parte, la preocupación por la justicia conmutativa, en los intercambios entre particulares no puede estimarse como disociada de las consideraciones relativas a justicia distributiva. Esta última clase de justicia erróneamente se ha considerado que no pertenece al derecho privado. Mas, si aquello fuere así, piensa Gordley, “[...] tendríamos que preguntarnos por qué debería importar, en el derecho privado, si una persona se enriquece al privar a otro de sus recursos" $\$ 2$.

Los criterios de distribución de recursos no pueden asociarse a la mera arbitrariedad, luego, un agente tiene los recursos que tiene, porque existe un sistema para efectuar la distribución de los recursos vigentes en la sociedad. La cuestión se resuelve no solo en términos de equidad sino también de pragmatismo, porque al privar un contratante a otro de aquello que le corresponde, desestima la razón en virtud de la cual el contratante lesionado ha adquirido aquello de lo que se le priva. Proviene del sentido común conciliar la justificación de la obligatoriedad de la regla contractual con elementos de ambas especies de justicia, ya que la generalidad de las personas admiten que los recursos externos pueden ayudar a vivir una vida mejor y, a su vez, la misma generalidad considera que puede poseer una parte más o menos equitativa de los recursos ${ }^{43}$. Si la distribución de los recursos se aleja de un esquema ideal, la legislación es apta para proteger a los derechos de las personas a sus propios recursos, alcanzando un ideal de vida aristotélico sin que la redistribución de las riquezas deba efectuarse, ex ante, por los particulares ${ }^{44}$.

${ }^{41}$ Gordley (2006), p. 12.

42 Gordley (2006), p. 13.

${ }^{43}$ Gordley (2006), p. 14.

${ }^{44}$ Para una reconstrucción intelectual sobre los fundamentos filosóficos de la doctrina moderna del contrato, véase Gordley, James (1991). The Philosophical Origins of Modern Contract Doctrine. Oxford: Clarendon Press. Ahí se indican con claridad las profundas fisuras existentes entre la tradición del derecho natural y 


\subsubsection{Autonomía de la voluntad como fundamento estándar}

De forma indubitada, al reflexionar en la justificación de la obligatoriedad de la relación contractual debemos ubicarnos bajo el campo de operatividad de la autonomía de la voluntad. Quizás las palabras de Immanuel KANT transparenten el rol de este principio en el surgimiento de las genuinas obligaciones morales. De acuerdo al filósofo de Königsberg, "[1]a autonomía de la voluntad es el único principio de todas las leyes morales, así como de los deberes que se ajustan a ellas; en cambio toda heteronomía del albedrío, lejos de fundamentar obligación alguna, se opone al principio de dicha obligación y a la moralidad de la voluntad" 45 . El privilegio que KANT predica de la autonomía de la voluntad como fundamento de las obligaciones morales y jurídicas que contraemos, descansa en el origen estrictamente racional de la ley universal cuya validez, en tanto tal, es independiente de todo aspecto material o empírico. Según lo veremos, cumplir lo que autónomamente hemos pactado, no constituye una virtud, como lo consideraría ARISTÓTELES o una acción correcta porque tiende a la felicidad general, reafirmando los intereses de la práctica contractual, como se desprende de la intuición utilitarista, sino una acción por deber, es decir, una actuación por una máxima que es posible universalizar. Dicha obligación se decanta de la razón pura que se otorga sus propias leyes, con total independencia de algún elemento fenoménico, alguna consideración asociada a las consecuencias que se siguen, o bien actuaciones desplegadas por inclinación, tales como serían creer que se cumple el contrato porque su observancia es virtuosa o bien que contribuye al bienestar general.

Bajo el contexto del derecho privado patrimonial, y con cada vez mayor pertinencia en el ámbito extrapatrimonial, la autonomía de la voluntad reclama constituirse como el centro de todas las miradas. Según Manuel Somarriva, este principio puede "[...] condensarse en el conocido aforismo según el cual en el Derecho Privado puede hacerse todo lo que la ley no ha, expresamente, prohibido" ${ }^{46}$. Quizás sea en materia contractual donde se manifiesta la mayor aplicación de la voluntad de las partes al momento de generar, modificar y extinguir sus relaciones jurídicas obligatorias. Su poder normativo se considera discrecional y absoluto, puede ser ejercido según sus estimaciones personales y no requiere de alguna intervención externa para desplegarse. Gracias a este principio, los individuos, "[...] son libres para contratar o no según su deseo y parecer. La ley ni el juez pueden obligarlos a ello y, por lo tanto, la negativa de contratar no les puede aca-

las reformulaciones que sufrió la reflexión sobre el contrato durante el siglo XIX, junto a la influencia del liberalismo en el derecho de los contratos.

${ }^{45}$ Kant, Immanuel (2000). Crítica de la Razón Práctica [Kritik der praktischen Vernunft]. Aramayo, Roberto R. (Trad.), Madrid: Alianza, \$59, p. 101.

${ }^{46}$ Somarriva, Manuel (2010). "Algunas consideraciones sobre el principio de la Autonomía de la Voluntad". En: Doctrina Civil Chilena en el Bicentenario 1810-2010. Santiago: Editorial Jurídica de Chile, p. 109. 
rrear ninguna consecuencia jurídica” ${ }^{37}$. Prácticamente, toda la construcción de la teoría de los vínculos obligacionales entre los particulares reposa sobre la base de la autonomía de la voluntad.

De manera que conviene examinar los orígenes intelectuales de la noción de autonomía de la voluntad, que fueron recogidos en el programa de la codificación decimonónica de la cual nuestro Código Civil fue heredero. Es posible concebir el sistema jurídico privado como un sistema jurídico ilustrado, ya que las repercusiones del movimiento ilustrado en el ámbito privado radican, principalmente, en dos: la codificación como paradigma y la estructuración de un sistema jurídico legalista ${ }^{48}$. En ambas dimensiones se devela lo que está en juego en el proyecto iluminista; a saber, la autonomía. KANT en su “Respuesta a la pregunta, ¿Qué es la Ilustración?”, sugirió que aquella consistía en "[...] la salida del hombre de su autoculpable minoría de edad”'49. Dicha culpabilidad le correspondía al sujeto, porque él no carecía de facultades sino que no tenía el valor para comenzar a emplear autónomamente las potenciales de las cuales goza. La solución perlocucionaria de KANT radica en el jsapere aude!, es decir, en la exigencia a atreverse a pensar por sí mismo, sin la ayuda de otros. La apuesta ilustrada es una apuesta por la autonomía, y un consecuente rechazo por la heteronomía. La influencia del esquema kantiano de la autonomía moral para la legitimidad de nuestras obligaciones morales y jurídicas, se transparentó gracias al trabajo intelectual de Charles FrIED, cuya posición se analizará a continuación ${ }^{50}$.

\subsection{Fried y el contrato como promesa}

La publicación de Contract as Promise: A Theory of Contractual Obligation en 1981, constituye una articulación trascendental para la legitimación moral de la obligatoriedad del contrato. Según FrIED, en sus relaciones de cooperación, los individuos suponen que el resto de los partícipes no solo respetarán sus derechos, sino que además participarán activamente en la materialización de sus intereses. Si

\footnotetext{
47 SOMARriva (2010), p. 109.

${ }^{48}$ Respecto al paradigma de la codificación y sus ideologías, véase TARELLO, Giovanni (1995). "Ideologías del siglo XVIII sobre la codificación y estructura de los códigos" [Le ideologie della codificazione nel secolo XVIII]. En: Cultura Jurídica y Política del Derecho. Rosas Alvarado, Isidro (Trad.), México D.F.: Fondo de Cultura Económica, pp. 39-56. En relación a la configuración de un sistema jurídico legalista mediante la promulgación del Código Civil de Bello, puede consultarse FigueroA, María Angélica (1982). "La codificación civil chilena y la estructuración de un sistema jurídico legalista”. En: Andrés Bello y el Derecho, Santiago: Universidad de Chile, pp. 77-104.

${ }^{49}$ Kant, Immanuel (2009). “Respuesta a la pregunta: ¿Qué es Ilustración?” [Beantwortung der Frage: Was ist Aufklärung?]. En: ¿Qué es la Ilustración?, Maestre, Agapito y Romagosa, José (Trad.), Madrid: Tecnos, p. 17. Cursivas del original.

${ }^{50}$ Una versión anterior sobre el análisis del contrato como promesa y su discusión contemporánea que gobierna el apartado siguiente, puede consultarse en PereIra Fredes, Esteban (2010b). "El contrato como promesa y su discusión contemporánea", en Artificium. Revista Iberoamericana de Estudios Culturales y Análisis Conceptual, Vol. 1, México D.F., pp. 49-72.
} 
dicha suposición es acompañada de la convicción según la cual los demás actuarán conforme a un estándar de corrección moral, entonces es posible afirmar que se confía en aquel supuesto.

El valor de la confianza se encuentra asociado a la promesa. Esta le brinda fuerza a la confianza y deviene en su efectiva normatividad. En la ejecución de una empresa o una actuación determinada que procura la satisfacción de intereses propios, una vez que el agente decide no efectuarla por sí mismo sino de modo conjunto, la promesa cobra el valor que FRIED le atribuye. Al desarrollar voluntariamente una promesa de actuación, nuestras expectativas se centran sobre la confianza en la ayuda prometida. De ahí que al prometer "[...] transformamos una elección moralmente neutra en moralmente apremiante" ${ }^{1}$. Así, la promesa le sirve de insumo moral a la confianza, proveyéndole de su fuerza normativa en la verificación de la acción o prestación prometida. Después de formulada la promesa, su transgresión se estima incorrecta, no obstante la misma actuación resultaba irrelevante para los agentes antes de su verificación.

Un aspecto significativo del entendimiento de FRIED radica en no agotar suficientemente su comprensión del término promesa. Para el nacionalizado estadounidense, la promesa es una comunicación verbal cuya carga moral se expresa según la veracidad o no que tenga aquello que se dice. Un acto de habla tiene una pretensión de verdad respecto a la afirmación que se formula, pero la promesa implica comprometerse a actuar con posterioridad. Es una oferta potencial de actuación que se evalúa correcta o incorrectamente según se mantenga o quebrante la promesa. De lo anterior no se sigue que el promitente no pueda cambiar de propósito o evaluación respecto al mismo. En efecto, es plenamente libre para modificar sus motivaciones, mas no lo está para romper la promesa formulada ${ }^{52}$.

De modo problemático FRIED asume una estrategia argumentativa según la cual para determinar el papel moral de la promesa es necesario descartar ciertas ideas que cotidianamente se predicarían de la formulación de una promesa. Ya mencioné que la promesa no coincide necesariamente solo con la verdad de la intención que se sostiene. Tampoco lo hace el eventual beneficio que se puede obtener o el daño que se puede causar con el incumplimiento de la promesa. De una parte, si el agente cambia de parecer con posterioridad a la formulación de la promesa, y obtiene una ganancia, esta se consideraría como injusta, exigiéndosele

\footnotetext{
${ }^{51}$ FrIED, Charles (1996). La obligación contractual. El contrato como promesa [Contract as Promise: A Theory of Contractual Obligation]. Ruíz-Tagle Vial, Pablo (Trad.), Santiago: Editorial Jurídica de Chile, p. 20.

52 John L. Austin afirmó que el prometer constituye un ejemplo de un verbo realizativo del cual se formulan emisiones realizativas. Dicha emisión se encuentra constituida por un solo acto y no está configurado sobre la base de dos actos, en que el acto prometido se encontraría precedido de un acto psicológico o mental del agente. Fried, por el contrario, concibe al acto de prometer mediante una estructura compleja, conjugada a partir de dos actos correlativos; a saber, la comunicación verbal y el comportamiento futuro que se sigue de la respectiva locución. Para el entendimiento de Austin, véase Austin, J. L. (1999). "Emisiones realizativas" [Performative utterances]. En: La buisqueda del significado, García SuÁreZ, Alfonso (Trad.), Madrid: Tecnos, pp. 419-434.
} 
la restitución de lo que indebidamente ha adquirido. Pero dicha injusticia no se genera del enriquecimiento ni es fuente de la obligatoriedad de su restitución. Y, de otra, al reducir la fuerza moral de la promesa al daño que sufre el contratante que actúa por la confianza que le inspira la promesa del promitente y los daños que sufriría si se rompe, se incurre en el mismo problema. Defraudar la confianza depositada en la promesa constituiría la justificación para la obligación de compensar el daño causado, así como también fundamenta a la obligación de restituir lo injustamente ganado, pero supone que el agente es responsable en tanto pudo haber previsto que el móvil de la acción del otro radica en la confianza y también respecto al daño que se le causaría al quebrantar la misma ${ }^{53}$.

Siguiendo a FrIED, la actuación que nos demanda una promesa no solo hace referencia a la sinceridad actual, sino a la confianza respecto de una actuación futura. De ahí que la formulación de la promesa conlleva el valor de verdad de la afirmación y, a su vez, importa necesariamente el compromiso a realizar algo que excede a la veracidad de la intención manifestada. Lo peculiar de la explicación es reconocer que la apelación del beneficio y la actuación por confianza intentan explicar la fuerza de la promesa, a partir de dos de sus efectos característicos. Sin embargo, la vigencia de ambas explicaciones depende de reconocer previamente la fuerza del compromiso ${ }^{54}$. Resulta paradójico que ello se resuelva en la medida que se acepte la circularidad del argumento; la promesa tiene valor en un supuesto particular si se asume previamente su fuerza general. Solo a partir de esto es posible efectuar la atribución moral de los efectos producidos intencionalmente. Este reconocimiento, piensa FrIED, está detrás de toda estructura convencional, sean las instituciones jurídicas, las prácticas y, en general, aquellas de índole lingüística. Después de todo, prometer es una convención que corresponde a un uso del lenguaje y reconoce una diversidad de propósitos particulares. Así, al comprometernos podemos realizar actos de generosidad, garantizando que el otro pueda verificar su proyecto, pero más allá de esta inspiración altruista del compromiso, lo central radica en la ganancia recíproca que demanda la obligatoriedad de la promesa.

Es cierto que el planteamiento de Fried aún no clarifica por qué el agente está obligado a cumplir una promesa. Si bien FRIED sugiere una noción de la promesa, según la cual esta consiste "[...] en una manera en que me puedo obligar a mí mismo en favor de otro, de modo que éste pueda esperar una prestación futura; y de este modo, el obligarme a mí mismo es algo que puedo elegir" ${ }^{55}$, no demuestra en qué sentido el prometer implica una obligación moral de cumplir la promesa,

\footnotetext{
${ }^{53}$ Un antecedente temprano sobre esta discusión, en SHARP, F. C. (1934). "The ethics of breach of contract”. International Journal of Ethics, Vol. 45, No 1, pp. 27-53. Para el cuestionamiento de esta tesis, véase SHAVELL, Steven (2005). "Is breach of contract immoral?" Harvard Law and Economics Discussion, Paper No 531, pp. 1-28.

${ }^{54}$ FrIED (1996), p. 24.

${ }^{55}$ FrIED (1996), p. 28.
}

Revista de Derecho · Escuela de Postgrado No 6, diciembre 2014 
aunque su observancia sea inconveniente o costosa para su agente. Dicha labor se sostiene en dos alternativas posibles: las sanciones externas y la obligación moral. Respecto a esta última, FRIED rechaza que la mantención de la promesa se justifique mediante un argumento de mera utilidad, afirmando que su obligatoriedad descansa en la autonomía individual y la confianza en su cumplimiento ${ }^{56}$.

En este sentido, la obligación individual a la cual se da origen en virtud de la promesa exige a su autor mantenerla, porque este ha invocado una convención que otorga fundamentos morales para que la otra parte tenga la expectativa de que la promesa será cumplida. Incumplir la promesa conlleva abusar de la confianza que libre e intencionalmente formuló y cuya expectativa de observancia fue generada por el propio promitente. De ahí que la transgresión de la confianza se asimile, pero no equivalga en estricto rigor a mentir; ya que el promitente se aprovecha "[...] de una institución social compartida que tiene por objeto apelar a los lazos de confianza” ${ }^{57}$. Pero ambos, quien miente como quien rompe una promesa libremente manifestada, están usando al otro; pues generan expectativas basadas en la confianza y, mediante la incorrección respectiva, abusan de aquella. La obligatoriedad de la promesa se extiende más allá del deber de decir la verdad, ya que la pretensión de verdad se verifica el momento en que afirma el enunciado lingüístico y, en cambio, la promesa obliga hacia futuro, extendiendo su observancia aun con posterioridad a su formulación.

A diferencia de la propuesta utilitarista, que afirmaría la importancia de hacer cumplir el contrato por las consecuencias beneficiosas que se producirían para los ciudadanos, la adopción del contenido moral del deber de su cumplimiento, concibe a la promesa como un instrumento generado por agentes morales libres, y cuya fuerza se sustenta en la confianza mutuamente depositada. En términos generales, el promitente tiene un deber de mantener su promesa y en el ámbito contractual, en tanto dimensión particular, la promesa contractual tiene la peculiaridad que su obligatoriedad es también jurídica. FRIED es categórico respecto a la continuidad conceptual entre el contrato y la promesa: “[...] puesto que el contrato es una promesa antes que ninguna otra cosa, debe cumplirse del mismo modo" 58 .

Al contextualizar la intuición de FRIED en el marco de la filosofía kantiana, de la cual el primero reconoce su conexión, es posible obtener resultados clarificadores para la evaluación de la concepción clásica del contrato o, en términos del autor, contrato como promesa. La tesis de KANT, de inspiración deontológica, supone que no es posible encontrar nada que sea bueno en sí mismo, salvo la buena voluntad. Dicho estándar normativo se alcanza en la medida que las acciones se ejecuten por el deber y no por inclinación. Una acción es correcta por el motivo de deber que exige necesariamente su cumplimiento, con prescindencia de las consecuencias

56 Fried (1996), p. 30.

57 Fried (1996), p. 30.

${ }^{58}$ Fried (1996), p. 31. 
beneficiosas que eventualmente se puedan seguir de aquel. Solo cuando se actúa por deber la máxima individual alberga un contenido genuinamente moral. Así, el valor moral de la acción no radica en el propósito que aquella persigue, sino en virtud del principio del querer en razón del cual ha sucedido tal acción, al margen de las consecuencias que se pudieren producir.

Según el filósofo de Königsberg, el deber "[...] significa que una acción es necesaria por respeto a la ley”, y de ahí que únicamente actuar por representación de la ley en sí misma constituye un bien moral para los seres racionales ${ }^{59}$. De acuerdo a la razón práctica, para que una acción tenga valor moral es necesario que sea derivada a partir de leyes y de este modo la voluntad fuere restringida y determinada según la razón. La regla suprema de moralidad se encuentra exclusivamente asociada a mandatos, como expresiones del deber ser, que expresan una acción como objetivamente necesaria por sí misma, con indiferencia a algún fin ulterior, y que Kant identifica con el imperativo categórico ${ }^{60}$. Como verdadero imperativo de la moralidad, este reconoce su valor en la formulación autónoma del agente moral: es la libertad fundada en el mundo nouménico la cual le permite al individuo limitar su voluntad, predicando racionalmente sus acciones de leyes objetivas. De este modo el agente moral se configura como un legislador universal a través de sus máximas de la voluntad.

La noción de promesa en KANT constituye un ejemplo al cual recurre en numerosas ocasiones para desarrollar su argumentación. Precisamente pues para él prometer expresa un imperativo categórico. Para KanT la máxima "no debes prometer con engaño" no se formula como un consejo que invita a ponderar el posible descrédito que eventualmente le significaría al promitente ser descubierto, sino que le implica una prohibición incondicionada. Su carácter apodíctico deviene en la obligatoriedad del cumplimiento de la promesa, pues la máxima que la contiene importa la necesidad de una acción que en sí misma se estima buena. No obstante, el uso de la promesa como expresión de una máxima con mérito moral, se vuelve problemática a la luz de la primera formulación del imperativo categórico. Dicha regla reza en los siguientes términos: "obra sólo según aquella máxima por la cual puedas querer que al mismo tiempo se convierta en una ley universal"61. Aquella da cuenta de la necesidad de un precepto para obrar, como lo es la observancia a las promesas libremente formuladas, que pueda universalizarse y exigirse respecto de todos los seres racionales, sin excepción.

No cabe duda que el cumplimiento de las promesas conlleva adecuarse a un criterio de corrección moralmente válido, pero en el esquema kantiano puede significar una inconsistencia respecto a la imposibilidad de desatender de forma

\footnotetext{
59 Kant, Immanuel (2005). Fundamentación para una Metafísica de las Costumbres [Grundlegung zur Metaphysik der Sitten]. Aramayo, Roberto R. (Trad.), Madrid: Alianza, p. 74.

${ }^{60}$ Kant (2005), p. 94.

${ }^{61}$ KANT (2005), p. 104
} 
absoluta una orientación hacia las consecuencias de las acciones. Una interpretación contrafáctica de la máxima que envuelve a las promesas exige evaluar los efectos que su quebrantamiento produciría tanto en el agente como en la sociedad. Después de todo, defraudar la confianza depositada en la promesa no solo importa vulnerar la propia voluntad expresada, cuya mantención es garantizada por la confianza que respecto a ella existe, sino también importa poner en riesgo el sistema de intercambio cooperativo basado en la confianza recíproca. Si no se observasen las promesas libremente formuladas, no sería posible articular un modelo social en el cual sea posible satisfacer nuestros intereses y alcanzar los propósitos mediante actuaciones conjuntas. La fidelidad a las promesas posee un valor intrínseco y de ahí que deban necesariamente respetarse pues, de lo contrario, se producirían efectos significativamente negativos para la humanidad.

FRIED pareciere hacerse parte de esta lectura teleológica del planteamiento ético kantiano, en tanto asimila buena parte del valor de respetar la máxima según la cual debemos cumplir nuestras promesas en las consecuencias perniciosas que su quebrantamiento ocasionaría al ámbito contractual en particular y, a la confianza entre los miembros de la sociedad, en general. Pese a concluir estableciendo que "[...] en virtud de los principios kantianos básicos de confianza y respeto, es incorrecto invocar esta convención [la práctica de prometer] para hacer una promesa y luego romperla”, descuida en su justificación a ideas centrales en el pensamiento del prusiano como lo son la autonomía individual y la dignidad ${ }^{62}$. Actuar por principios que poseen un valor intrínseco importa observarlos sin que su valor radique en el provecho o utilidad que ello conlleve, ya que su cumplimiento responde al respeto inmediato a máximas de la voluntad, aun cuando no sean favorecidas por el éxito. Si esto es así, el ser racional autónomamente se obliga, y solo obedece a las leyes que él mismo ha legislado y de acuerdo a las cuales sus máximas pueden formar parte de la legislación universal, a la cual asimismo se somete. La observancia a dichas normas determina el valor incondicionado e incomparable que constituye el ser racional, a quien se le reconoce su propia naturaleza como fin en sí mismo y legislador en el reino de los fines. Según KanT, “[...] la autonomía es el fundamento de la dignidad de la naturaleza humana y de toda naturaleza racional"63.

\subsubsection{Esquemas no-normativos de comprensión}

\subsubsection{Kelsen y las condiciones de imputación}

El programa de la Teoría Pura del Derecho formulada por el vienés Hans KeLSEN significó un hito transcendental en la tradición analítica de la filosofía del derecho ${ }^{64}$.

${ }^{62}$ Fried (1996), p. 31.

${ }^{63}$ Kant (2005), p. 125.

${ }^{64}$ Un esfuerzo de reconstrucción de la tradición analítica de la filosofía del derecho, junto a sus momentos de autocomprensión en Pereira Fredes, Esteban (2014b). "Tradición analítica de la filosofía del derecho". 
La teoría jurídica analítica reflexiona sobre sí misma, situando a la propia filosofía del derecho como objeto de estudio, y preguntándose cuáles serían los genuinos objetivos de la reflexión jurídica, así como cuáles serían las explicaciones que cabría esperar del despliegue de su quehacer teórico. En efecto, purificar el estudio del fenómeno jurídico sugiere una actividad epistémica de delimitación en el sentido de aclarar el propósito de la filosofía del derecho. Según Kelsen, el objetivo de su investigación procura tematizar "[...] a la pregunta de qué sea el derecho, y cómo sea; pero no, en cambio, a la pregunta de cómo el derecho deba ser o deba ser hecho. Es ciencia jurídica; no, en cambio, política jurídica" ${ }^{65}$. Para estos efectos, es necesario articular una categórica demarcación entre el ámbito jurídico y todo aquello que no pertenece al derecho, i.e. moral, política y cuestiones ideológicas en general. Un estudio se podrá preocupar del mundo de los fenómenos y otro distinto se hace cargo del mundo de las normas, pero la teoría jurídica necesariamente adopta la segunda modalidad, desplazando el interés de todo elemento ajeno al fenómeno jurídico.

Un acontecimiento externo producido en el mundo natural regido por las leyes de la naturaleza, carece de significación jurídica por sí mismo. Todo suceso logra su significación específicamente propia en el derecho, mediante "[...] una norma que se refiere a él con su contenido, que le otorga significación en derecho, de suerte que el acto puede ser explicitado según esa norma"66. De ahí que la norma kelseniana opera como un esquema de explicitación conceptual. Los actos humanos adquieren su significación de derecho gracias a una norma jurídica que la hace explícita en términos normativos, presentándose como un objeto digno de estudio para la ciencia del derecho. A partir de esta perspectiva, un mero hecho factual como el intercambio de cartas entre dos individuos adquirirá significación jurídica, en términos de constituir la celebración de un acuerdo o vínculo contractual, siempre que exista una norma jurídica cuyo contenido coincida con el supuesto factual.

A diferencia del ámbito del ser donde los estados de cosas se ajustan a un principio de causalidad, según el cual a un antecedente sigue una determinada consecuencia, el mundo del deber ser se rige por el principio de imputación. Mientas el primero sostiene que si se produce el hecho A también se producirá el hecho $\mathrm{B}$, el segundo dispone que cuando se da $\mathrm{A}$, debe ser $\mathrm{B}$. Es decir, la relación entre una condición y una consecuencia es factual y, en cambio, la conexión entre la verificación de un supuesto y la imputación de consecuencias jurídicas, es una relación normativa. Esta identidad se refleja en el empleo de las normas del verbo deber, luego, "[...] si alguien deja de pagar sus deudas, deberá ejecutarse civilmente su patrimonio"67.

En: Problemas Actuales de la Filosofía Jurídica, Santiago: Librotecnia, pp. 283-322.

${ }_{65}$ Kelsen, Hans (1982). Teoría Pura del Derecho [Reine Rechtslehre]. Vernengo, Roberto J. (Trad.), México D.F.: UNAM, p. 15.

${ }^{66}$ KeLSEN (1982), p. 17.

${ }^{67}$ Kelsen (1982), p. 104.

Revista de Derecho · Escuela de Postgrado No 6, diciembre 2014 
Bajo el marco contractual se conserva el planteamiento kelseniano sobre el fenómeno jurídico general. Para KELSEN, así como para el conjunto de la dogmática civil, el contrato constituye el negocio jurídico de mayor importancia y aplicación. De modo que " $[\mathrm{e}] \mathrm{n}$ un contrato acuerdan las partes contratantes deber comportarse recíprocamente de determinada manera" ${ }^{68}$. Un negocio jurídico enfrenta una faz subjetiva como otra objetiva. El sentido subjetivo se expresa en el deber de comportamiento, pero también aquel representa su sentido objetivo porque constituye un acto productor de normas jurídicas y, en base a tal calidad, la realización del negocio jurídico, junto a una conducta contraria a este, se establecen como condición de una sanción civil. Desde luego, las partes contratantes al reglamentar sus relaciones contractuales no establecen sanciones, "[...] sino una conducta cuyo opuesto es una condición de la sanción estatuida por las normas generales" ${ }^{69}$. Dicha norma jurídica general establece una sanción asociada a la obligación principal de omitir la conducta contraria al pacto negociado, de modo de provocar así un daño y, a su vez, una obligación accesoria relativa a reparar el daño provocado por la infracción de la obligación principal. Se desprende de lo anterior que el contratante podrá evitar dicha sanción en base a dos modalidades: observando la obligación principal que el negocio jurídico ha establecido, o bien, en el evento que haya incumplido lo pactado, a través del cumplimiento de la obligación accesoria consistente en reparar el daño provocado.

Al observar la estrategia de KELSEN para evaluar la fuerza obligatoria del contrato, resulta evidente la fractura de su enfoque con los esquemas normativos de justificación del efecto vinculante. La nomenclatura que adopté para dar cuenta de este segundo grupo explícitamente escinde las nociones de justificación y comprensión. Una modalidad explicativa, como la formulada por el vienés, no puede ser entendida como un intento por afrontar la legitimidad de la fuerza obligatoria de la relación contractual. Pues le basta por comprender cómo a partir del principio de imputación, quien celebra un contrato debe cumplir las prestaciones contraídas o, en su defecto, deberá observar las obligaciones de reparación de los perjuicios que su infracción principal provoque. Como se indicó con anterioridad, en el cumplimiento del contrato, se explicita la operatividad de la norma jurídica que otorga significación normativa a la interacción fáctica. KELSEN pone a prueba la tesis central de los esquemas de justificación de la regla contractual, ya que es posible describir cómo aquella opera sin necesidad de argumentar por qué sería deseable la existencia de esta regla.

\subsubsection{Law and Economics}

El programa de investigación del análisis económico del derecho se construye sobre la base de efectuar una reformulación de los parámetros bajo los cuales una

\footnotetext{
${ }^{68}$ KeLSEN (1982), p. 264.

69 KeLsen (1982), p. 264.
} 
explicación podría calificarse como satisfactoria en la reflexión sobre el fenómeno jurídico $^{70}$. En lugar de problematizar la justificación de las instituciones y reglas jurídicas, opta por evaluar el rendimiento de criterios económicos sobre aquellas, a partir de nociones como eficiencia y distribución de recursos económicos. No obstante, el Law and Economics no niega que la autonomía de la voluntad constituye el fundamento del derecho de los contratos, según Rodrigo BarCia LEHMANN, su peculiaridad descansa en que "[...] estructura el contrato sobre las expectativas del acreedor y, especialmente, sobre las expectativas de las partes"71. Esta aproximación renuncia a las pretensiones justificadoras de la institución contractual, ya que su prisma de análisis es de carácter pragmático. Si las preguntas centrales que la reflexión jurídica sobre los contratos radican en determinar (i) ¿qué promesas deben cumplirse legalmente?; y (ii) ¿cuál es el remedio para enfrentar al incumplimiento de las promesas legalmente exigibles?, es necesario dar cuenta de ambas interrogantes alejándose de la tesis estándar de justificación; a saber, la teoría de la negociación de los contratos ${ }^{72}$.

Dicha propuesta normativa afirma el principio de la negociación, conforme al cual "una promesa es legalmente exigible cuando se formula como parte de una negociación; de otro modo, una promesa no es legalmente exigible”73. Bajo estos términos, se construye el criterio de distinción entre aquellas promesas que gocen de exigibilidad y aquellas que carezcan de tal necesidad. De ahí que las promesas formuladas en virtud de una consideración serán jurídicamente obligatorias y, a su vez, las promesas que carezcan de una consideración no son jurídicamente obligatorias. Este criterio permite, al momento de responder la primera pregunta, diferenciar la razón de la exigibilidad de la justicia que en lo particular puede presentar una determinada negociación. Así, los tribunales de justicia pueden acceder a la exigibilidad del vínculo contractual sin necesidad de supervisar la justicia de la negociación mediante la cual el acuerdo tuvo lugar. La segunda interrogante se responde en términos correlativos a la primera. Si la negociación supone un beneficio que las partes contratantes razonablemente podrían esperar alcanzar gracias al acuerdo, el remedio para enfrentar la inobservancia de la obligatoriedad de la promesa se devela en los daños a dicha expectativa contractual. De manera que

\footnotetext{
${ }^{70}$ Esta aproximación ha sido calificada, por Carlos Peña González, como el nuevo paradigma en derecho civil. A diferencia del esquema clásico, su énfasis se encuentra situado en las decisiones, es decir, en los outputs del sistema jurídico, desenvolviendo sus estudios a la luz de una racionalidad estratégica. Al respecto, véase, Peña González, Carlos (1995). "Los desafíos actuales del paradigma del Derecho Civil". Estudios Públicos, No 60, pp. 327-348.

${ }^{71}$ Barcia Lehmann, Rodrigo (2004). "Los efectos de las obligaciones desde la perspectiva del análisis económico". En: Cuadernos de Análisis Jurídicos: Colección de Derecho Privado, Tomo I, Temas de Responsabilidad Civil, Santiago: Ediciones Universidad Diego Portales, p. 136.

${ }^{72}$ Cooter, Robert y Ulen, Thomas (1998). Derecho y Economía [Law and Economics]. Corrales, Carlos Floriano (Trad.), México D.F.: Fondo de Cultura Económica, p. 230.

73 Cooter y Ulen (1998), p. 230. Cursivas del original.
} 
"[e]l hecho de una negociación establece la obligación legal, y el valor esperado de una negociación mide los daños"74.

Bajo este orden de observaciones, ¿podría articularse alguna alegación que justifique incumplir el acuerdo contractual? Ciertamente no. Por lo mismo, una comprensión económica de lo jurídico propone sustituir la teoría de la negociación con una teoría económica sobre el contrato, esto es, una propuesta "[...] menos dogmática, que dé más respuestas" ${ }^{\prime 5}$. Al deslindar el cumplimiento de las promesas de eventuales deberes normativos, traduciendo el problema al lenguaje de la eficiencia económica, puede resultar eficiente realizar una conducta aun cuando su mérito moral sea deficiente. Así, tiene sentido hablar de adscribir a las nociones de cumplimiento e incumplimiento el predicado de eficiente. Las fórmulas corresponden a las siguientes:

Cumplimiento eficiente:

Costo del cumplimiento para el promitente < beneficio del cumplimiento para el receptor de la promesa.

Incumplimiento eficiente:

Costo del cumplimiento para el promitente > beneficio del cumplimiento para el receptor de la promesa.

La cuestión valorativa sobre el cumplimiento de los acuerdos deviene en un problema relativo al cúmulo de incentivos que tendrá el promitente para cumplir su promesa. Ambas fórmulas se condensan según lo siguiente: "[...] el promitente tiene incentivos eficientes para cumplir e incumplir cuando la responsabilidad por el incumplimiento se iguala al beneficio perdido por el receptor de la promesa"76. Luego, si nos enfrentamos, por ejemplo, a un contrato de compraventa, sabemos que el vendedor se obliga a dar la cosa y, a su vez, el comprador a pagarla en dinero, según los términos del artículo 1793 del Código Civil. Dada la fuerza obligatoria del vínculo contractual legalmente celebrado, los contratantes no pueden sino cumplir el contrato. Sin embargo, si dos contratantes acuerdan la venta de un bien en un precio (x) y después de celebrar el negocio jurídico, el vendedor recibe la oferta de un segundo y nuevo comprador que ofrece el precio $(\mathrm{x})$, pero aumentado en $100(x+100)$, las condiciones de posibilidad de cumplimiento e incumplimiento del pacto ya celebrado, se examinan según la eficiencia y los incentivos de adoptar ambas respuestas.

${ }^{74}$ Cooter y Ulen (1998), p. 235.

75 Cooter y Ulen (1998), p. 237.

${ }^{76}$ Cooter y Ulen (1998), p. 245. 
El ordenamiento jurídico puede considerar el incumplimiento como eficiente en la medida que se compense al acreedor en su expectativa rota. Por ejemplo, si consideramos que el contrato inicial contemplaba una cláusula penal equivalente a 10 , para sancionar al contratante que incumpliere las estipulaciones contractuales convenidas, estamos ante un supuesto de incumplimiento eficiente, toda vez que aun cuando el vendedor repare el daño en las expectativas contractuales de su primer comprador, de igual modo es eficiente la inobservancia del primer contrato, ya que habrá una repartición genérica de riquezas a favor de los distintos integrantes del supuesto. A partir del incumplimiento eficiente, todos los participantes se encuentran en una mejor posición en comparación a su condición anterior a la contratación. Mientras el vendedor queda con el precio $(x+90)$, el comprador defraudado dispone de 10, equivalentes al pago de la multa civil; y, finalmente, el segundo comprador tiene en su poder el bien objeto del contrato de compraventa.

Al igual que Hans KELSEN, el análisis económico del derecho interpreta a la fuerza obligatoria de la relación contractual a la luz de criterios que exceden al valor moral que reporta su vigencia. Si el primero traducía su significación a las condiciones de imputación que las normas jurídicas atribuyen a los supuestos factuales condicionales, el segundo propone efectuar una fractura entre la justificación valorativa de la fuerza obligatoria del contrato, de un lado, y las consideraciones de eficiencia económica a las cuales tanto el cumplimiento como incumplimiento aspiran, de otro.

Según se ha desarrollado en el transcurso de esta sección, si bien es posible descartar la necesidad de evaluar críticamente el fundamento de la regla contractual mediante un razonamiento exclusionario, existen esquemas conceptuales desplegados desde una perspectiva normativa. Y, a su vez, otras teorías rivales que procuran comprender la obligatoriedad de los contratos, mediante una metodología descriptiva, sin necesidad de justificar o afirmar lo deseable que puede estimarse la existencia de una regla que fije el efecto contractual obligatorio. Bajo este orden de consideraciones, la tesis de mayor suscripción en los estudios sobre derecho privado es la de Charles Fried. Las dificultades que se generan al respaldar su aproximación radican en suscribir el dogma decimonónico de la voluntad como el fundamento de la obligatoriedad contractual, bajo el nuevo escenario de la contratación contemporánea, donde la autonomía de la voluntad ha extraviado su valor inicial, adquiriendo pertinencia la intervención legislativa que caracteriza al derecho de contratos desde inicios del siglo $\mathrm{XX}^{77}$.

\footnotetext{
77 El derecho contractual ha sido caracterizado, por autores como Patrick S. Atiyah, en atención a su preeminencia de razones de forma, bajo las cuales se fijan institucionalmente consideraciones que determinan la validez de ciertos actos jurídicos y establecen derechos y obligaciones correlativos por la verificación de tal formalidad. Dichas razones desplazan a las razones de sustancia de su consideración judicial. No obstante lo anterior, la influencia de las razones de forma se ha debilitado progresivamente, permitiendo que los jueces exploren el fondo de los negocios y atiendan a razones sustanciales para la atribución o exclusión de obligaciones. Al respecto, véase Atryah, P. S. (1986). "Form and Substance in Contract Law". En: Essays on Contract, Oxford: Clarendon Press, pp. 93-120.
} 
Al hablar de un escenario contractual contemporáneo, entiendo un conjunto de principios y reglas que han reformulado los paradigmas decimonónicos de la contratación, fracturando la identidad entre relación contractual y voluntad. El contraste con el contexto anterior se encuentra formulado en virtud de la significativa intervención del legislador en los vínculos contractuales entre particulares, presentándose tanto en la generación de los contratos como en la determinación del contenido de las prestaciones que los gobiernan. El progresivo desplazamiento de la voluntad del ámbito contractual vigente desde comienzos del siglo XX, pudiere evidenciar dificultades al momento de adscribir la cuestión de la legitimación de la fuerza vinculante del contrato, sobre su imagen conceptual de constituir una declaración de la voluntad de las partes, según la cual se forzó la contratación moderna $^{78}$.

Un reflejo de esta reformulación se encuentra en las categorías contractuales que se reconocen en los distintos ordenamientos jurídicos privados, los cuales tensionan la identidad entre contrato y voluntad y, por consiguiente, podrían ofrecer obstáculos para mantener a la voluntad libremente expresada como bastión de la obligatoriedad contractual ${ }^{79}$. Como sabemos, estas categorías contractuales radican en los contratos de adhesión, contratos dirigidos y contratos forzosos. No hace falta transitar detenidamente por cada uno de ellos, del modo en que se efectúa bajo la teoría general del contrato, para advertir que en las formas contemporáneas de contratación la voluntad de las partes es muchas veces dejada en un segundo plano, cuestionando que la voluntad pueda aún cumplir el rol que bajo el estadio de la codificación se creyó satisfacía. Mi interés en la próxima sección es evaluar en qué sentido el regreso a la preliminar noción de autonomía personal podría efectuar un trabajo satisfactorio para servir de fundamento normativo a la regla contractual, no obstante los presupuestos ilustrados de la simetría en la racionalidad y en el poder de los negociantes haya sido puesta a prueba en el desenvolvimiento de las prácticas contractuales cotidianas. Porque, como agudamente lo ha sugerido Hanoch SHEInMan, esos postulados son parte de la vieja ortodoxia del derecho contractual ${ }^{80}$.

\footnotetext{
${ }^{78}$ Una reconstrucción intelectual sobre el tránsito entre el inicio, auge y declive de la libertad contractual bajo el contexto jurídico anglosajón en АTIYAH, P. S. (1979). The rise and fall of freedom of contract. Oxford: Oxford University Press, especialmente, pp. 219-291; 716-779.

${ }^{79}$ Las categorías contractuales admiten interpretarse como un resultado de la constatación sobre la incongruencia existente entre la libertad de los individuos para contratar y la realidad de las prácticas contractuales. Como lo indica Daniel Peñailillo Arévalo, "[l]a amplia libertad conduce a resultados frecuentemente injustos, pues se observa que los individuos no son enteramente libres, sino están muchas veces forzados por las circunstancias que los rodean; y como las presiones son distintas, tampoco son iguales, siendo frecuente la inferioridad (superioridad) de unos frente a otros, por diferencias de variado signo, generalmente económico". Véase, Peñailillo Arévalo, Daniel (2003). Obligaciones. Teoría general y clasificaciones. La resolución por incumplimiento. Santiago: Editorial Jurídica de Chile, p. 38.

${ }^{80}$ Sheinman, Hanoch (2000). "Contractual liability and voluntary undertakings". Oxford Journal of Legal Studies, Vol. 20, No 2, pp. 205-220.
} 


\section{AutonOmía COMO JUSTIFICACiÓN DE LA FUERZA OBLIGATORIA}

Culmina la línea argumentativa del presente trabajo, mediante el examen del ideal regulativo de la autonomía personal como un criterio idóneo para desempeñar la justificación normativa de la obligatoriedad del contrato. Una vez fundamentada la necesidad de esgrimir razones justificativas para la institución del contrato y su efecto vinculante, se explorará el sentido de la noción de autonomía en nuestras relaciones contractuales. El artículo 1545 será tematizado a partir de las esferas de realización autónoma que ofrece a los contratantes. Su potencial explicativo nos ayudará a develar el significado que tienen para los participantes del ámbito contractual, las reglas jurídicas del sistema jurídico privado, como mecanismos institucionales para materializar la autonomía de los agentes. De igual forma, el derecho privado puede ser interpretado en términos de su compromiso con la autonomía de los individuos en el diseño de sus planes de vida. Como se verá, no existe una diferencia drástica entre la justificación de la fuerza obligatoria del contrato y las exigencias a las cuales responde el derecho privado.

\subsection{La necesidad de una justificación ética del contrato}

De acuerdo a las consideraciones esgrimidas en la primera sección, existen esquemas de comprensión contrapuestos para dar cuenta de la fuerza vinculante consagrada en la regla jurídica contractual. Mientras los modelos normativos estiman que la obligatoriedad del vínculo contractual se sigue de criterios valorativos sujetos a la tesis bajo la cual se realice la respectiva alegación, las perspectivas instrumentales rechazan la necesidad de una legitimación normativa para examinar al efecto obligatorio del contrato, proponiendo una sustitución de los parámetros normativos por nociones de eficiencia económica. El incumplimiento contractual afirmado como correcto según alguna de las teorías de justificación, puede devenir ineficiente cuando el propósito es la generación e incremento de nuevas riquezas entre los agentes racionales.

También se indicó que es ciertamente posible, más erróneo, eludir la tematización normativa del artículo 1545 del Código de Bello, mediante un examen de dicha regla jurídica como una razón excluyente para la acción. Esta consideración atribuye una constitución binaria a la regla contractual, interpretando que brinda una razón de primer orden para que los contratantes cumplan lo pactado según los términos en que los obliga la legislación y, además, una razón de segundo orden, relativa a abstenerse de evaluar el mérito de toda otra consideración que contradiga al cumplimiento incondicionado. Como se sugirió, el articulado del texto legal sirve como una razón formal para la atribución de obligaciones a las partes contratantes, marginando toda clase de consideraciones de sustancia adicionales. Dicha atención formalista se comunica también a una interpretación lógica de la figura contractual, formulada sobre la base de condiciones de imputación de consecuencias jurídicas, por la verificación de los supuestos factuales consagrados por la norma jurídica.

Revista de Derecho · Escuela de Postgrado No 6, diciembre 2014 
De manera que la pregunta que inspira a este trabajo se encuentra expuesta a un desplazamiento si se empleare un razonamiento exclusionario de la regla contractual, o bien evitando esta modalidad, pero negando que el efecto obligatorio del vínculo contractual requiera de una justificación en términos normativos. Si bien correspondería analizar al artículo 1545, no hay razón para sostener que su examen exceda de criterios estrictamente formales, o se distancie de nociones de eficiencia y conlleve exigencias adicionales de corrección. Esta sección pretende argumentar a favor de una necesidad de justificar valorativamente la obligatoriedad de la relación contractual. Con posterioridad se presentará la propuesta de justificación normativa que, en consecuencia de lo anterior, correspondería ofrecer.

La noción de contrato y su fuerza vinculante responden a consideraciones que solo pueden abarcarse de un modo satisfactorio si asumimos la comprensión de lo jurídico que se encuentra en juego en estas nociones. Para una visión moderna del derecho no corresponde entender a lo jurídico como una deducción racional derivada de la naturaleza inmutable. El derecho y, en especial, sus instituciones constituyen hechos institucionales que valen lo que valen porque los individuos así lo han determinado. La validez del derecho descansa en constituir un acto de voluntad política ${ }^{81}$. A su vez, las instituciones jurídicas se justifican ya que responden a decisiones adoptadas por los agentes, sin que aquellas dependan conceptualmente de un estado preexistente de cosas. El fenómeno jurídico resuelve su pertinencia en constituir un artificio humano destinado a solucionar un problema de cooperación. Un aspecto significativo de la funcionalidad del derecho radica en evitar la inseguridad que es razonable sostener existiría si no hubieren reglas jurídicas que coordinen y gobiernen las acciones e interacciones espontáneas entre los sujetos. Como todo artefacto o invención, lo jurídico justifica su existencia en la instrumentalidad que presta para quienes participaron en su generación. En palabras de Neil MACCormick, "[...] los artefactos e inventos humanos, incluyendo las reglas bajo las que las personas tratan de vivir, o conseguir que otras vivan, tienen que ser entendidas funcionalmente" 82 .

De manera que, desde un prisma moderno, el derecho no resiste ser explicado sin develar las consideraciones valorativas a las cuales su vigencia responde. Dada su correspondencia a un acto de creación de la voluntad política debe ser justificado en tales términos. El vocabulario del fenómeno jurídico asociado a facultades y

\footnotetext{
${ }^{81}$ Detmold, M. J. (1989). “Law as Practical Reason”. The Cambridge Law Journal, Vol. 48, No 3, pp. 440-443.

${ }^{82}$ Maccormick, Neil (2011). Instituciones del Derecho [Institutions of Law]. Atria, Fernando y Tschorne, Samuel (Trad.), Madrid: Marcial Pons, p. 376. Con todo, hay que tener presente que los sistemas jurídicos resuelven problemas de coordinación mediante la dictación de reglas jurídicas, que no necesariamente poseen un sustrato valorativo como soporte. Aquello sucede con la regulación del tránsito, al elegir entre conducir por el costado derecho o izquierdo de la calzada. Dicha opción no responde a una decisión sustantiva entre criterios normativos en competencia, pero si no existiere la regla se provocaría un problema de coordinación. No toda regla jurídica debe entenderse según su fundamentación valorativa, mas sí toda institución jurídica determinante en el diseño de un sistema jurídico debiere examinarse según su sustento valorativo. Debo este punto a Alberto Pino Emhart.
} 
obligaciones descansa en un complejo de ideales de vida, que componen su genuino sustrato valorativo. ¿Podemos decir lo mismo respecto del vínculo contractual? Ciertamente sí, pero teniendo presente el rol que cumple el contrato como expresión del ideal regulativo del autogobierno, modernamente proclamado en las relaciones interpersonales en general y jurídicas en lo particular. La institución del contrato constituye un hecho institucional de nuestra configuración social y quizás sea el principal hecho institucional.

John SEARLE ha observado la relevancia de los hechos institucionales en la construcción de la realidad social, diferenciándolos de los hechos brutos ${ }^{83}$. Mientras estos últimos ocurren de forma física o mental con independencia de cualquier institución humana, los hechos institucionales solo existen dentro de las instituciones humanas. Los hechos institucionales son creados mediante la asignación de funciones externas a un fenómeno mediante la intencionalidad colectiva. Dicha asignación no se explica en virtud de los rasgos intrínsecos del fenómeno, sino por la atribución externa de su nuevo estatus para cumplir la nueva función que ha sido determinada por la intencionalidad colectiva. De acuerdo a SEARLE, "[e]sa asignación crea un nuevo hecho, un hecho institucional, un hecho nuevo creado por acuerdo humano" 84 .

Si esto fuere así, el derecho consiste en un cúmulo de instituciones cuyo estatus o función ha sido asignada por la intencionalidad colectiva. Como a determinados trozos de papel se les atribuye el estatus de dinero y cuentan como moneda de curso legal para pagar y extinguir deudas, el derecho cumpliría su función como un mecanismo de composición de conflictos sociales en la comunidad. Ello se devela en especial por referencia al contrato como una figura jurídica estándar, cuya validez es colectivamente aceptada y reconocida. De ahí que modernamente el derecho no puede sino ser entendido en el marco de la estructura de hechos institucionales, bajo los cuales funcionan las sociedades humanas. Desde luego, este esquema teórico se robustece en términos políticos al considerar que el derecho gobierna la conducta de los seres humanos de forma autónoma, porque aquellos han decidido gobernarse mediante reglas jurídicas por sí mismos dictadas. El estándar normativo del autogobierno se distancia de las consideraciones heterónomas del derecho pre-moderno, cuya fuente de legitimidad excedía al ser humano, y como lo sabemos, se expresa con claridad en los términos de Jean-Jacques RoussEAU, en alusión a la libertad moral que se obtiene bajo el estado civil, es decir, "[...] la única que convierte al hombre verdaderamente en amo de sí mismo, porque el impulso exclusivo del apetito es esclavitud y la obediencia a la ley que uno se ha prescrito es libertad" 85 .

\footnotetext{
83 SeArle (1997), pp. 49-53.

${ }^{84}$ SeArle (1997), p. 63.

85 Rousseau, Jean-Jacques (2007). El Contrato Social o Principios de Derecho Politico [Du Contrat Social]. De Los Ríos, Fernando (Trad.), Madrid: Tecnos, p. 22.
} 
La relación contractual tiene mucho que decirnos al momento de articular una concepción moderna sobre el fenómeno jurídico. Su estrecha conexión con la noción de artificialidad e implementación del gobierno autónomo de los individuos mediante reglas libremente convenidas, transparentan su carácter institucional. Los contratos brindan mecanismos institucionalizados de coordinación de las agencias individuales, pero de su identidad institucional se predican funciones de liberación y estabilización. En este sentido, Arnold GEHLEN sugirió que una antropología filosófica madura propiciaba una fractura entre el mundo natural y el social, en cuyo contexto al ser humano le corresponde la transformación activa del plano natural $^{86}$. Esta modificación humana es correlativa al tipo de intervención que el individuo ejecuta en el ámbito natural, porque esa intervención busca dar cuenta de lo que es su interpretación sobre el ámbito natural. La afectación ejercida por el individuo devela el sentido de su concepción del mundo sobre cómo debiere ser el esquema natural. Su intervención busca estabilizar al mundo natural a partir de las consideraciones normativas del agente. De ahí que el instrumento para afectar el ámbito que preexiste a los individuos sean precisamente las instituciones sociales.

Desde un punto de vista social, la interrupción desplegada satisface las dos funciones antes señaladas ${ }^{87}$. Por una parte, una función de liberación en virtud de la cual la institución contribuye a descargar las expectativas y objetivos de individuos. Por otra, una función de estabilización que procura estabilizar las expectativas y necesidades de los intervinientes. Como se podrá imaginar, las instituciones sociales se autonomizan de quienes las construyen, cobrando con posterioridad a su acto de constitución una vida propia. Bajo el supuesto del vínculo contractual, tales funciones resultan ineludibles. El contrato libera las expectativas normativas de comportamiento estimadas como prudentes por los individuos y, a su vez, las estabiliza mediante pautas de cooperación recíproca desde las cuales emanan relaciones obligatorias, protegidas por el sistema jurídico privado. Su carácter moral se encuentra asociado a las directivas y puntos de estabilización definidos por los contratantes, "[...] cuyo designio consiste en garantizar la seguridad e inmutabilidad de las relaciones sobre una base de confianza mutua" ${ }^{\text {. }}$.

No debe perderse de vista que precisamente el diagnóstico del contractualismo moderno, como el de HoBBEs, radica en efectuar una escisión entre la condición natural del ser humano y el estado civil. Pese a que no exista una formulación explícita, el autor entiende al estado de naturaleza por oposición al estado civil. Donde no existe soberano, cabría sostener teóricamente la presencia de la condición natural del hombre. Esto explica por qué mientras el estado de naturaleza se caracteriza por la ausencia de justicia, propiedad y derecho, el segundo los contiene,

${ }^{86}$ GeHlen, Arnold (1993). Antropología filosófica: del encuentro y descubrimiento del hombre por sí mismo [Man: His Nature and Place in the World]. Cienfuegos W., Carmen (Trad.), Barcelona: Paidós, pp. 36-40.

87 GeHLEN (1993), pp. 88-92.

${ }^{88}$ Gehlen (1993), p. 38. 
en la medida que existe un adjudicador que puede determinar qué es lo correcto e incorrecto, así como lo tuyo y lo mío ${ }^{89}$.

Según HobBes, el estado de naturaleza corresponde a una potencial guerra de todos contra todos. Es decir, este supuesto no requiere que efectivamente exista conflicto entre los agentes, sino que basta con una disposición manifiesta a la lucha mientras no exista un poder común. Existe una constante guerra bajo la cual el ser humano podría resultar destruido por los demás. La contraposición entre estado de naturaleza y estado civil se evidencia, en los términos de HobBes, porque el primer orden de cosas se extenderá "[...] durante el tiempo en que los hombres viven sin un poder común que los atemorice a todos [...]"90. Como sabemos, la vida del ser humano en el estado de naturaleza fue categóricamente descrita por el autor como solitaria, pobre, tosca, embrutecida y breve.

El contrato social es un mecanismo para salir de un determinado estado de cosas. Su estatus se disuelve en su aptitud para permitir una configuración normativamente deseada. De modo que un constructo humano, como el vínculo contractual, promueve la cooperación entre los agentes, reemplazando la lucha por el acuerdo. Dicha visión del contrato da cuenta de su existencia instrumental y, de ahí, que no pueda ser correctamente entendida su verificación o fuerza vinculante sin atender a aquello para lo cual sirve. Ahora bien, al procurar cubrir la específica relevancia del contrato bajo el contexto de las instituciones sociales, respecto de las cuales hemos indicado que pertenece, las consideraciones anteriores persisten. El contrato, junto a otras instituciones sociales, requiere necesariamente de alguna justificación normativa para develar su pertinencia ${ }^{91}$. Nociones como contrato, castigo y propiedad se encuentran expuestas a una inagotable tematización. El mérito epistémico de estas dimensiones de análisis radica en el tipo de instituciones de las cuales se trata y la funcionalidad que aquellas cumplen en los asuntos humanos. ¿Cuál es la peculiaridad de estas instituciones sociales?

Jeremy WaLDRON estableció que el estudio de la propiedad debía estar dividido en dos órdenes de problemas ${ }^{92}$. De un lado, problemas analíticos relativos a la clarificación conceptual de términos asociados al derecho propietario y, en especial, la diferenciación de las distintas especies de propiedad que conviven bajo el género de propiedad, como lo son la propiedad privada, colectiva y común. De otro, problemáticas normativas asociadas a contraponer y evaluar los distintos esquemas de justificación que se encuentran en disputa para enfrentar a la propiedad, como ocurre con las afirmaciones favorables a su presencia sostenidas en

\footnotetext{
${ }^{89}$ Hobbes (1992), p. 104.

${ }^{90}$ Hobbes (1992), p. 102.

${ }^{91}$ Esta dimensión social del vínculo contractual es destacada en Suchman, Mark C. (2003). "The Contract as Social Artifact". Law \& Society Review, Vol. 37, No 1, pp. 91-142.

92 Waldron, Jeremy (2010). "Property Law". En: A Companion to Philosophy of Law and Legal Theory. Oxford: Blackwell, pp. 9 y ss.
} 
los modelos del individualismo posesivo y la concepción revolucionaria heredada del pensamiento francés, o bien los alegatos críticos que promueven la supresión de la propiedad privada y reemplazo por la propiedad común, como sucede con el pensamiento marxiano.

Ambos niveles de problemas son prima facie trasladables hacia otras nociones institucionales como el contrato y el castigo. Ello se explica, piensa WALDRON respecto de la propiedad, en base a tres criterios de justificación de estas construcciones convencionales ${ }^{93}$. En primer lugar, la propiedad constituye una institución social primordial y su consagración se encuentra constituida por una decisión política, correlativa a una organización de recursos que bien podrían ser utilizados en una cuestión distinta. Ya nos hemos pronunciado sobre el carácter social del vínculo contractual y de los argumentos hobbesianos se extraen las razones bajo las cuales resulta prudente contratar en lugar de no hacerlo ${ }^{94}$. El pacta sunt servanda constituye la ratificación institucional por parte del poder político acerca de su consideración favorable como institución que fomenta y resguarda la cooperación de los individuos.

En segundo lugar, hay costos de oportunidad y objeciones morales a las cuales se enfrenta la propiedad. Existen costos de oportunidad porque su existencia desplaza a la alternativa adversarial, esto es, su supresión. Si la propiedad priva de la posibilidad de poseer algo a quienes nada tienen, en virtud del desplazamiento de la idea de propiedad, entonces, se requieren consideraciones valorativas acerca de por qué aquella es socialmente aceptable. A su vez, hay poderosas objeciones morales involucradas, dado que la propiedad conlleva exclusión, segmentación y sufrimiento a quienes carecen de ella. Solo bastaría detenerse en los problemas de estratificación social que se generan a partir de la existencia de la propiedad privada bajo un sistema jurídico. De igual forma, el contrato se expone a estas dificultades. Hay costos de oportunidad porque es posible afirmar que la relación contractual no supone una coordinación simétrica entre los agentes que propicia el ordenamiento jurídico, sino una mera expresión de la imposición violenta de la voluntad del contratante que cuenta con un privilegiado poder económico y social, en desmedro de los intereses de quien se caracteriza por su debilidad jurídica. Como pudiere indicar una aproximación crítica sobre los contratos de adhesión. El escenario contractual contemporáneo, al cual nos referimos anteriormente, se encuentra al servicio de esta interpretación.

Desde estas consideraciones también subyacen problemas en su legitimación moral. El fomento y protección jurídica de los vínculos contractuales entre par-

\footnotetext{
93 Waldron (2010), pp. 14 y ss.

${ }^{94}$ Este esquema interpretativo sobre la tesis contractualista ha sido desarrollado por David Gauthier, quien sostiene que "[...] Hobbes expresa una visión directamente maximizadora de la acción racional [...]". Gauthier, David (2000). La moral por acuerdo [Morals by Agreement]. Bixio, Alcira (Trad.), Barcelona: Gedisa, p. 215. De manera que bajo este estado de cosas, resulta racional disponerse a cooperar que optar por la no cooperación.
} 
ticulares requiere de una justificación de segundo orden, en torno a la excesiva importancia que tienen los contratos como medios de distribución de riquezas bajo el contexto de las democracias liberales contemporáneas. Un enfoque distante de los valores defendidos por este orden político esgrimirá sus legítimas dudas acerca de la justificación del régimen contractual. No obstante lo anterior, incluso si nos situamos en este esquema de organización social, la obligatoriedad del vínculo contractual admite defraudar exigencias de justicia contractual, ya que la estricta observancia a los términos pactados puede ocasionar la ruina de uno de los contratantes, obligando a cumplir en condiciones excesivamente onerosas y desconocidas al momento de manifestar su voluntad de suscribir la relación jurídica. La pertinencia de la teoría de la imprevisión, que antes asociamos a una razón sustantiva vigente pese a la progresiva intervención legislativa en el campo contractual, constituye una cuestión de legitimación normativa, según la cual el artículo 1545 del Código Civil puede generar profundas situaciones de incorrección moral por la fuerza obligatoria.

En tercer lugar, la propiedad privada supone agudos problemas de diferenciación. El desplazamiento de la propiedad a favor de un adquirente es socialmente complejo, porque el propietario se define en torno a su capacidad para excluir a los demás de la cosa sobre la cual recae su derecho propietario. Sin embargo, cuando aquel propietario es perturbado en el ejercicio de su derecho de dominio, el resto de la sociedad que fue sistemáticamente privada de lo suyo, concurre en su protección jurídica. Esta inconsistencia se agudiza al observar los problemas distributivos de las transferencias de dominio, porque como lo indica WALDRON, se cautela a un sistema de control de los recursos "[...] que deja a unos pocos con mucho, a un gran número con muy poco y a un número considerable de participantes sin absolutamente nada" 95 . ¿ Podemos decir algo muy distinto sobre la regulación jurídica del contrato? El contraste no resulta significativo y es evidente que la relación jurídica contractual formulada bajo el dogma de la voluntad, que fue proclamado por los filósofos de la burguesía revolucionaria a fines del siglo XVIII, se ajusta a una postura en filosofía de la política que promovía intercambios entre agentes con un simétrico poder negociador, cuyos presupuestos conceptuales fueron puestos a prueba y, asimismo, denunciándose sus efectos nocivos en contra de ciertos contratantes o consumidores, para diseñar nuevas regulaciones de protección y salvaguardar la asimetría que en realidad caracteriza al escenario contractual.

De acuerdo a las observaciones antes desplegadas, el vínculo contractual responde a una de las instituciones sociales cuya trascendencia únicamente se transparenta al justificarla en términos normativos. No son suficientes las razones descriptivas que explican el contexto de descubrimiento de la institución contractual, sino que adicionalmente se requieren razones evaluativas sobre la aceptabilidad de esta

95 Waldron (2010), p. 14. 
institución social y su obligatoriedad jurídica. Si un contrato no puede desligarse de su legitimación moral, su fuerza obligatoria necesita de consideraciones críticas sobre la razonabilidad de su vigencia. La regla contractual, consagrada en el artículo 1545 de nuestro texto legal, no es solo una regla jurídica que impone excluyentemente un mandato de observancia de las prestaciones, también devela una sustantiva decisión política acerca de cómo debemos organizarnos en nuestras interacciones, desplazando las objeciones sobre los costos de oportunidad, problemas morales y efectos de diferenciación social que, según lo indicamos, debe enfrentar un esquema contractual.

\subsection{Propuesta de una justificación normativa}

\subsubsection{Kimel y la autonomía personal}

Examinar la pertinencia de justificar a la obligatoriedad del vínculo contractual a partir de criterios normativos de legitimidad, supone reconocer previamente que la institución jurídica del contrato requiere necesariamente de una fundamentación de raigambre ética ${ }^{96}$. Durante los párrafos precedentes, se intentó proveer de razones en tal sentido. La fuerza vinculante de la relación contractual depende necesariamente de razones normativas que indiquen por qué es razonable la existencia y conservación de una regla jurídica, prescrita en el sentido plasmado por nuestro codificador. Desde esta perspectiva, la búsqueda de esta justificación normativa está sujeta a alguno de los esquemas valorativos de justificación, analizados durante la primera sección. Y, desde luego, la renuncia a los modelos de eficiencia propuesto por el análisis económico del derecho $\mathrm{y}$, a su vez, al formalismo normativista kelseniano, bajo el cual el problema justificativo se disolvía por la estructura lógica de las reglas jurídicas ${ }^{97}$.

En este sentido, ya se advirtió sobre la relevancia que el modelo justificativo de Charles Fried alcanzó en la reflexión acerca del contrato. En sus términos, el efecto vinculante de la relación contractual es aceptable por el respeto a la promesa moral que un contratante efectúa a favor de otro cuando contrata, resultándole su promesa de comportamiento como normativamente apremiante, al generar legítimas

\footnotetext{
${ }^{96}$ Una postura según la cual el incumplimiento del contrato, así como la infracción a la promesa que sustenta el vínculo contractual, no necesariamente importa una situación incorrecta o inmoral, en la medida que los contratos no prevén los acontecimientos que aleatoriamente pueden suceder durante su vigencia, puede consultarse en SHAVELl (2005), pp. 1-28.

${ }^{97}$ La estrategia de reconstrucción funcional sostenida por el análisis económico del derecho, interpretando a las reglas del sistema jurídico privado en términos de meros incentivos o desincentivos para la consecución de conductas socialmente deseadas, genera dificultades al momento de reconocer la dimensión normativa del derecho privado. De manera que el problema de la justificación de la fuerza obligatoria del contrario, se disuelve en una explicación sobre el comportamiento estratégico de los contratantes. Una defensa de la normatividad del derecho privado en SMITH, Stephen A. (2011). "The Normativity of Private Law”. Oxford Journal of Legal Studies, Vol. 31, No 2, pp. 215-242.
} 
expectativas sobre su conducta contractual en su contraparte. Su reconocimiento, como un esquema paradigmático dentro de la filosofía del derecho privado contemporánea, exige detenernos en su evaluación. Sus méritos explicativos ceden a favor de sus deficiencias. Pues el valor epistémico de la aproximación de FrieD deviene circunscrito a un sistema jurídico como el anglosajón, donde efectivamente existe una relación conceptual entre las nociones de contrato y promesa ${ }^{98}$. Bajo un sistema jurídico privado perteneciente a una tradición legal alternativa, como nuestra regulación continental, resulta menester explorar un fundamento normativo distinto a la promesa moral, y dotado de una mayor dimensión de compatibilidad con el escenario contractual formalmente caracterizado por la paulatina intervención del órgano legislativo en el derecho de contratos, desde comienzos del siglo XX.

Si la explicación de FRIED presentaba un déficit en la identificación del criterio normativo en la promesa que formula el contratante, basada en la confianza y el respeto reconocidos como imprescindibles en las relaciones de cooperación humanas, ello no obsta a que la propuesta de FRIED pueda contribuir a configurar el marco dentro del cual es posible justificar el deber de observancia de las obligaciones contractuales ${ }^{99}$. Su planteamiento indudablemente traza los lineamientos bajo los cuales se puede formular satisfactoriamente la empresa objeto del presente trabajo. En lugar de abandonar la perspectiva valorativa de comprensión de la regla contractual, conviene robustecer dicha propuesta en términos normativos. Para estos efectos, el énfasis no se situará tanto en la promesa moral, como en la noción de autonomía de los contratantes. Y, asimismo, se explorarán dimensiones de reformulación de la noción de autonomía, acercándola a sus genuinas raíces intelectuales, adaptándola al ámbito contractual contemporáneo y, finalmente, asociándola al tipo de reglas que gobiernan al sistema jurídico privado.

Bajo estas consideraciones, un modelo explicativo que interesa destacar es el articulado por Dori KIMEL. Según se indicó anteriormente, FrIED sostuvo la normatividad del contrato como promesa de acuerdo a un esquema propio del pensamiento kantiano. De ahí que si el contrato constituye una promesa, aquel debe

\footnotetext{
${ }^{98}$ Las sustantivas diferencias existentes entre la tradición jurídica anglosajona y la de raigambre romana respecto al régimen contractual pueden examinarse desde la óptica de unificación en la figura unitaria del contract que asume el derecho inglés. En este sentido, Dell'Aquila, Enrico (2001). El Contrato en Derecho Inglés. Tomo I. Elementos del contrato y vicios de la voluntad. Barcelona: PPU, pp. 25-43. Acerca del derecho de los contratos bajo el common law, resultan de significativa importancia las sistematizaciones de O'SULLIVAN, Janet e Hilliard, Jonathan (2012). The Law of Contract. Oxford: Oxford University Press; McKendrick, Ewan (2007). Contract Law. London: Palgrave Macmillan; y STONE, Richard (2008). The Modern Law of Contract. London \& New York: Routledge-Cavendish.

99 Esta comprensión del paradigma del vínculo contractual bajo un esquema relacional ha sido sostenida por Dori Kimel, para quien el contrato no solo implica un intercambio, sino también una relación entre las partes contratantes que, a diferencia de cualquier forma estándar de interacción humana, genera normas, o contribuye a las partes a definir sus expectativas, proporcionándoles fuentes de aseguramiento, facilitando la cooperación y creando interdependencia, incluso más allá de lo previsto por el contrato o las normas jurídicas. Al respecto, véase Kimel, Dori (2007). "The choice of paradigm for theory of contract: reflections on the relational model". Oxford Journal of Legal Studies, Vol. 27, o 2, pp. 233-255.
} 
ser cumplido pues su validez descansa en la confianza depositada en el promitente por el receptor de la promesa moral. Las relaciones de cooperación desarrolladas en procura de satisfacer intereses y expectativas de índole intersubjetiva exigen que la confianza mutua no sea defraudada y, si esto sucede, se transgrede el estándar normativo que implica el valor de la observancia a la confianza ${ }^{100}$. Un problema que enfrentaba esta intuición radica en no asociar suficientemente el valor intrínseco de la promesa al postulado kantiano de la autonomía individual. El respeto inmediato hacia el cumplimiento de la promesa, si es que el contrato responde a esta noción moral, deriva de la dignidad del ser racional que de forma autónoma deriva una máxima que forma parte de la voluntad universalmente legisladora, y que implica un deber incondicionado y objetivo de observancia.

Bajo estas consideraciones se conserva la necesidad de justificar normativamente al contrato, pero el punto de partida de esta propuesta se encuentra más estrechamente relacionado con el pensamiento del filósofo prusiano. Para Kimel " [...] la autonomía personal es un ideal de auto-creación de las personas que ejercen el control sobre sus destinos" ${ }^{101}$. El desarrollo de una vida autónoma consiste en el ejercicio de actividades de libre elección de los agentes, asociadas a sus propósitos y relaciones interpersonales. De igual modo que se apela a la autonomía individual para justificar la libertad contractual, su valor sirve de justificación para la fuerza vinculante de las promesas. La idea estándar radica en establecer que el reconocimiento del valor de la autonomía personal implica la preocupación por configurar las condiciones necesarias para que los agentes desarrollen una vida autónoma y, asimismo, prima facie, el respeto por sus actividades libremente escogidas. Si los agentes contraen voluntariamente obligaciones contractuales, la obligatoriedad de estas disposiciones decanta del respeto de la autonomía personal de los propios agentes. Incumplir los vínculos contractuales es mostrar falta de respeto por su autonomía.

Si bien este supuesto es significativamente válido, solo constituye un punto de partida para la fundamentación de la obligatoriedad de nuestras promesas y contratos $^{102}$. Una concepción liberal del contrato necesariamente reconoce el valor

\footnotetext{
${ }^{100}$ La conciliación entre el derecho contractual y las promesas presenta problemas metodológicos respecto a la compatibilidad conceptual de la formulación de la promesa contractual y la práctica de prometer, así como observaciones de orden sustantivo asociadas a la caracterización de la promesa contractual y su entendimiento cotidiano. Para un cuidado análisis sobre la separación entre las nociones de contrato y promesa, en tanto el contrato no constituye una instancia de la promesa, según entendemos cotidianamente a la práctica de prometer, de modo que corresponden a esferas distintas de la agencia moral, persiguiendo valores morales también diferenciados, véase BAGCHI, Aditi (2011). "Separating contract and promise". Florida State University Law Review, Vol. 38, No 709, pp. 710-758.

101 Kimel, Dori (2003). From Promise to Contract: Towards a Liberal Theory of Contract. Oxford: Hart Publishing, p. 126.

102 Respecto al origen de la obligación de cumplir nuestras promesas, fundamentando su normatividad en clave contractualista, véase SCANLON, Thomas (2003). Lo que nos debemos unos a otros. ¿Qué significa ser moral? [What We Owe to Each Other]. Weikert García, Ernest (Trad.), Barcelona: Paidós, pp. 371-410.
} 
de la autonomía personal, pero de forma alguna supone que aquella sea el único valor que puede resguardarse ${ }^{103}$. Y de ahí que no se exija un respeto indubitado a la fuerza vinculante de cualquier tipo de promesa contractual, con independencia de todo contenido o implicancias, esgrimiendo simplemente que se trata de actuaciones voluntarias de sujetos moralmente competentes. El contenido de los compromisos voluntarios responde a una pretensión de corrección característica del fenómeno jurídico, descartando una promesa, un contrato o incluso una cláusula contractual, que defraude un criterio de corrección moral, y ello es consistente con el compromiso de la teoría liberal del contrato de proteger y promover el valor de la autonomía personal, que, en principio, de modo alguno implica aceptar la fuerza vinculante de todas las promesas ${ }^{104}$.

Si esto es así, se explica de forma más satisfactoria que el resguardo de la autonomía personal en la obligatoriedad de las promesas no siempre implica mayor libertad para los agentes y menor intervención en su libertad contractual. Es efectivo que el ideal de la autonomía personal se encuentra asociado a la existencia de un margen amplio de posibilidades de elección, pero en el ámbito práctico su respeto no importa necesariamente desarrollar políticas de creación y de no obstaculización de la libertad de los agentes ${ }^{105}$. Al contrario, resulta aceptable que ciertas opciones y políticas restrinjan la autonomía individual, e incluso puedan impedir a una determinada persona ejercer esta opción, justificándose incluso en función del resguardo de su propia autonomía. La intervención regulatoria que en la actualidad experimenta el ámbito contractual no tiene por qué implicar necesariamente un socavamiento de la autonomía personal del agente moral, y con ello el desprestigio de la concepción liberal del contrato, pues dicha actuación legislativa, lejos de ser incompatible con el respeto a la autonomía, es ciertamente exigida por aquella.

Del mismo modo, las intervenciones legislativas que ha experimentado el sistema contractual tampoco implican un socavamiento de la aspiración de neutralidad liberal ${ }^{106}$. De la protección de la parte contractualmente más vulnerable frente a la más fuerte de la relación, se sigue que estas políticas no son neutrales respecto a los contratantes, así como no lo son sobre las cláusulas o contratos que se estiman incorrectos. De ahí que ciertas cláusulas o figuras contractuales se prohíban, adoptando una determinada concepción sobre lo bueno entre valores antagónicos. La

\footnotetext{
${ }^{103}$ La comprensión del contrato y su fuerza vinculante en virtud de la promesa y la transferencia de derechos entre los contratantes, ha sido formulada de acuerdo a los estándares del libertarianismo en el ámbito contractual. Al respecto, véase KINSELLA, N. Stephan (2003). "A libertarian theory of contract: title transfer, binding promises, and inalienability". Journal of Libertarian Studies, Vol. 17, No 2, spring, pp. 12-16.

${ }^{104}$ Kimel (2003), p. 128.

105 Acerca de las posibilidades de pertinencia que presentaría la libertad frente a las exigencias de igualdad y distribución de bienes de las sociedades contemporáneas, véase FrIED, Charles (1988). ¿Es posible la libertad? En: Libertad, Igualdad y Derecho: Las conferencias Tanner sobre filosofia moral. Barcelona: Ariel, pp. 93-132.

106 Kimel (2003), pp. 123-126.
} 
relación entre la autonomía personal y la neutralidad en el ámbito contractual es más compleja, pues la neutralidad se fundamenta en que el concurso de voluntades de las partes sea justo, reconociéndose como deseable que así sea, pero tal marco no puede serlo si existe un desequilibrio significativo entre ellas ${ }^{107}$. La neutralidad no conlleva una visión rígida de las obligaciones autónomas ni asumir idealmente todas sus implicancias contractuales, pues en aquellas circunstancias en que simplemente no es posible beneficiar a todas las partes o, en su caso, obstaculizarlas en el mismo grado, por existir una diferencia que justifique normativamente la intervención, es razonable que así suceda y ello es consistente con el estándar de observancia a la autonomía personal de los contratantes ${ }^{108}$.

\subsubsection{Autonomía individual como valor}

$\mathrm{Al}$ rescatar a las herramientas conceptuales que ofrece KIMEL para comprender la justificación de la fuerza obligatoria y su pertinencia bajo un contexto contractual de intervención legislativa, se presenta la alternativa metodológica de abandonar el acento en la voluntad y detenernos en el potencial explicativo que brinda la autonomía individual. Desde luego, esta afirmación pudiere estimarse como baladí si su objeción se basare en la estrecha relación que existe bajo los estudios de la dogmática civil entre autonomía privada y autonomía de la voluntad. Sin embargo, cabe escindir el tratamiento de ambas nociones porque pese a estar excesivamente vinculadas en la reflexión jurídico-privada no constituyen términos análogos ${ }^{109}$.

Durante el apartado 1.3.1.3.1, se tematizó la propuesta de Charles FrIED y en el marco del párrafo precedente, el enfoque de Dori KIMEL. ¿Qué podemos obtener de esta contraposición de exámenes? Sin duda, existe un acuerdo en la necesidad de fundamentar normativamente a la obligatoriedad del vínculo contractual, pero el contraste entre ambas aproximaciones se puede interpretar como una disputa acerca del énfasis efectuado sobre la lectura del problema, de lo cual no se sigue que exista un desacuerdo sobre tal lectura. Si FRIED concibe que el efecto obligatorio corresponde explicarlo en términos de la promesa moral que formulan los contratantes, al generar legítimas expectativas de confianza en su contraria, KIMEL alega que lo decisivo en las relaciones libremente desplegadas por los contratantes se sitúa en su

\footnotetext{
${ }^{107}$ Kimel (2003), p. 122.

108 Hanoch Dagan ha observado que el derecho privado suscribe una visión perfeccionista sobre la sociedad, imposibilitándolo de considerar neutralmente los distintos valores sociales en disputa. De ahí que el autor sugiera la renuncia a la demarcación radical entre las voces de autonomía e instrumentalización del derecho privado, proponiendo adoptar una infraestructura normativa que conjugue tanto las restricciones de la relación entre demandante y demandado, como los valores sociales que sean pertinentes para la interacción humana. Sobre esta consideración, véase DAGAN, Hanoch (2008). "The Limited Autonomy of Private Law". The American Journal of Comparative Law, Vol. 56, № 3, pp. 809-833.

109 Acerca de la noción, posición y papel que desempeña la autonomía privada en el campo del derecho privado, véase FERrY, Luigi (2001). La autonomía privada [L'autonomia privata]. MendizÁBAL, Luis Sancho (Trad.), Granada: Comares.
} 
autonomía personal, noción que es compatible con ciertos mecanismos formales de intervención legislativa. La promesa moral no puede robustecerse mediante la implementación de categorías contractuales que se entienden celebradas o exigen suscribirse bajo ciertos términos, pero sí la autonomía personal de los agentes, dado que tales intervenciones procuran hacerse cargo de quienes específicamente no cuentan con condiciones o medios suficientes para ejercer su agencia de individuos racionales. La protección de la especificidad de la autonomía personal es la cautela del efectivo despliegue de su agencia individual.

De todas formas, la lectura entre ambas propuestas es heredera del planteamiento kantiano. Anteriormente, se indicó que KIMEL invitaba a acentuar la relevancia de la noción de autonomía, un tanto descuidada por la tesis del contrato como promesa. Dicha sugerencia no solo permitía conciliar la autonomía de los agentes como fundamento obligatorio del contrato con el escenario de privilegio de razones institucionales advertido bajo las nuevas formas de contratación. También constituye una aproximación más genuina sobre aquello que se encuentra en juego en la observancia de obligaciones libremente formuladas; a saber, el respeto a nuestra autonomía individual. Una vez que la autonomía es honrada en nuestras prácticas e intercambios intersubjetivos, tiene sentido predicar la libertad de estas relaciones privadas y, a su vez, la vigencia del ideal del autogobierno en nuestra esfera pública. Quizás los estudios de derecho privado se encuentren encasillados en el influjo de la libertad decimonónica y su cuestionable asimilación a la voluntad de los agentes, perdiendo de vista a la autonomía personal ${ }^{110}$.

Si aquello fuere correcto, conviene recuperar sendos aportes de KANT y RousSEAU respecto del rol que cumple la autonomía como marco regulador de nuestra realidad. Al reconstruir las fuentes intelectuales de la propuesta de FRIED, se avanzó en las nociones involucradas de la extensa obra de KANT. Ahora bien, es posible que ciertas lecturas que se han mostrado estériles frente al aumento de la intervención legislativa en las relaciones contractuales, continúen reconociendo a la voluntad como el centro de su preocupación, desatendiendo el rol de la autonomía bajo el prisma kantiano. Desde KANT la voluntad no constituye por sí misma, como se pudiere pensar, un valor normativo. Solo se admite como tal, en la medida que sea autónomamente determinada por parte del agente racional. En sus términos, “[...] la voluntad libre tiene que ser determinada al margen de cualesquiera condiciones empíricas (o sea, pertenecientes al mundo de los sentidos), entonces una voluntad ha de encontrar en la ley, pese a todo, un fundamento determinante al margen de la materia de la ley"111. El contraste definitorio radica entonces en diferenciar a la autonomía con la heteronomía, porque ambos términos pueden actuar sobre

${ }^{110}$ Un agudo balance sobre la yuxtaposición entre autonomía y paternalismo bajo el derecho privado, se encuentra en la compilación de Ogus, Anthony y Van Boom, Willem H. (Eds.) (2011). Juxtaposing Autonomy and Paternalism in Private Law. Oxford: Hart Publishing, en especial, pp. 1-8; 145-173.

${ }^{111}$ KANT (2000), p. 94. Cursivas del original. 
nuestra voluntad. Únicamente, cuando la voluntad es autónomamente determinada tiene sentido predicar obligaciones del agente y su tematización como agente libre. Aun cuando se trate de una libertad no experimentable en el mundo de los fenómenos, sí es a lo menos teóricamente pensable.

Mientras la voluntad que está determinada por factores empíricos carece de mérito moral, por dejarse gobernar por inclinaciones y sensaciones ajenas a la razón, la voluntad determinada por la razón pura práctica goza de un genuino valor moral. De modo que la primera voluntad deviene heterónoma, mas la segunda corresponde a una voluntad propiamente autónoma. Como sabemos, el principio de la moralidad en KANT es la autonomía de la voluntad, pero la dogmática civil pudo fácilmente encandilarse con la visión decimonónica de la voluntad, desplazando a la autonomía que se exigía para generar verdaderas obligaciones normativas. Correctamente, esta teoría realizó una fractura entre las nociones de autonomía y voluntad, pero erróneamente perdió de vista lo central del principio de autonomía de la voluntad, esto es, que solo la presencia de autonomía hace de la voluntad un estándar normativo válido para obligarnos.

La voluntad puede transparentar dimensiones de heteronomía bajo las cuales un contrato puede presentar dificultades al momento de formular deberes de comportamiento a sus contratantes. Pero si este vínculo contractual derivó de una voluntad determinada por nuestra autonomía racional, entonces, se trata de una relación contractual necesariamente obligatoria, porque precisamente responde al ideal de la autonomía personal, que será reflejado por el imperativo de tratar a todos los seres racionales en tanto fines en sí. Tal vez las actuales formas de contratación debiliten la presencia de la voluntad en los intercambios particulares, pero difícilmente pudieren bloquear a la autonomía que los agentes despliegan en sus relaciones contractuales, cuyo resguardo en ocasiones de aguda asimetría exige la participación del órgano legislativo. De lo contrario, no podría sostenerse la obligatoriedad del vínculo contractual, a no ser que aquella se justifique en la autonomía personal de los contratantes.

De igual manera, los planteamientos de RouSSEAU permiten nutrir a la noción de la autonomía como rectora en nuestras relaciones privadas, de insumos de corte político que evidencien el carácter institucional del constructo contractual. Bajo la óptica de este autor, la autonomía de los individuos demuestra su potencial al momento de evitar el aniquilamiento de la especie humana, optando por agrupar colectivamente a las fuerzas ya existentes. ${ }^{112}$ Su idea del contrato social es ciertamente reveladora de nuestra esfera pública, pero también nos indica la comunicación que existe entre las obligaciones convenidas en nuestro ámbito privado y aquellas pactadas para constituir un orden político. Ambas se valen de la autonomía de los agentes y en la esfera pública cobra vigencia el ideal regulativo del autogobierno,

${ }^{112}$ Rousseau (2007), pp. 15-16. 
según el cual solo podemos políticamente gobernarnos según nuestros propios dictámenes. Aquel parámetro no es sino la traducción de la autonomía como fuente de legitimidad de los vínculos obligacionales en los asuntos públicos.

Lo relevante de este planteamiento radica en que no existen impedimentos para implementar mecanismos de cumplimiento forzoso para honrar a la autonomía que los agentes desplegaron en el nacimiento de sus relaciones obligatorias. Ya hemos hablado que según Rousseau la libertad que gana el agente en sus relaciones obligatorias en la esfera pública corresponde a una libertad de índole moral, pero este autor va un paso más allá que el diagnóstico kantiano, ya que la autonomía del agente racional no solo es fuente de la obligatoriedad sino que también conlleva la justificación para la intervención. Situados en el ámbito público, una voluntad que intente retractarse de lo pactado, puede y debe ser obligada a mantenerse en el pacto social, ya que la estructura civil depende de su estricta observancia.

Estas consideraciones válidas para la conservación de un orden político convenido, no tienen por qué traspalarse hacia el ámbito de nuestras relaciones privadas contractuales. No es cierto que siempre y en todos los casos, un vínculo contractual debe ser observado y el contratante obligado a cumplir lo pactado. Las razones de sustancia, que han cobrado fuerza a propósito de la teoría de la imprevisión, dicen lo contrario. No obstante, las alegaciones de RousSEAU dan cuenta de que modernamente son compatibles las nociones de autonomía e intervención, porque en teoría de la política es posible conciliar la libertad con la coacción ${ }^{113}$. Las razones que sirven de fundamento para la legitimidad de las obligaciones que nos debemos los unos a los otros, son replicadas para sostener deberes de observancia que permiten conservar el estado de cosas generado gracias a la actuación conjunta y autónoma de los sujetos. La autonomía gobierna tanto el ámbito privado como el público. De modo que bajo este último resulta pertinente la participación de modalidades de intervención destinadas a la protección y efectiva ejecución de la autonomía personal de los individuos ${ }^{114}$. Una versión madura sobre la noción de autonomía es flexible a esta clase de observaciones, frente a las cuales la voluntad decimonónica ofrecía dificultades.

No hay que olvidar que los distintos aspectos regulatorios que caracterizaban al régimen del derecho de contratos formulado desde comienzos del siglo XX, encuentran precisamente su justificación en consideraciones normativas de protección de la autonomía de los agentes. El origen autónomo de una prestación contractual

\footnotetext{
${ }^{113}$ Esto se refleja en los clásicos términos de Rousseau, según el cual para que el pacto social no sea una mera fórmula, encierra un compromiso tácito bajo el cual "[...] quien se niegue a obedecer a la voluntad general será obligado por todo el cuerpo; lo que no significa sino que se le obligará a ser libre [...]”. RousSEAU (2007), p. 21. Cursivas mías.

${ }^{114}$ Un agudo análisis sobre la idea de autonomía como auto-regulación y la evaluación de sus consecuencias para el derecho y la moralidad en Sieckmann, Jan-R (2012). The Logic of Autonomy. Law, Morality and Autonomous Reasoning. Oxford: Hart Publishing.
} 
no solo legitima su obligatoriedad en principio incondicional, sino que además autoriza la puesta en práctica de mecanismos de intervención pensados externamente a la relación contractual, para resguardar el fundamento de la obligatoriedad del contrato que descansa en la autonomía personal. Si aquello no fuere de esta forma, la autonomía tendría que ser ejercida en términos análogos por cada uno de los contratantes, y como ello no es así, entonces, las intervenciones contractuales no hacen sino hacer justicia a la tesis según la cual la autonomía personal puede erigirse como un digno fundamento de la fuerza obligatoria del contrato. Situado bajo un escenario de intensa regulación contractual como el contemporáneo, aquel valor normativo no hace sino fortalecerse.

Bajo estos términos, es posible comprender la trascendencia de pensar al contrato como una institución que transparenta una perspectiva moderna sobre el fenómeno jurídico, según la cual el derecho es puesto autónomamente por los agentes y no heredado heterónomamente de lo natural. Según lo indicamos en la sección 2.1, el carácter institucional de lo jurídico comprometía la necesidad de su justificación normativa y aquello se agudizaba tratándose de instituciones como la propiedad, el castigo y el contrato. Es innegable la identidad moderna del vínculo contractual y, sin tener presente este carácter, no es posible comprender por qué no se puede renunciar a brindar una legitimación valorativa de su fuerza obligatoria. Pero la propia formulación moderna del contrato exige interpretar su constitución y obligatoriedad, de acuerdo a los postulados que provee una comprensión moderna al fenómeno jurídico. De igual modo, como la libertad no implica una supresión absoluta de reglas imperativas y prohibitivas, la autonomía no debe ser modernamente interpretada como la erradicación de todo rasgo de intervención posiblemente heterónoma. El avance de un pensamiento como el hobbesiano hacia uno sensible a los argumentos de RoussEAu, devela que las reglas jurídicas expresan genuinas dimensiones de libertad y márgenes emancipatorios para los agentes. La forma estándar de desplegar nuestra agencia autónoma es a partir del fenómeno jurídico que hemos diseñado para la propia regulación.

Muchas observaciones críticas hacia la vigencia de la autonomía en un ámbito contractual diseñado mediante una fuerte reglamentación legislativa, oponen incorrectamente el derecho a la autonomía de los agentes, entendiendo que la legislación solo es una barrera que rige heterónomamente el accionar de los individuos. Si la imagen del dogma de la voluntad decimonónica informó el proceso codificador, corresponde examinarla bajo un prisma moderno de comprensión del derecho, bajo cuyos términos la ley puede ser expresión en algún sentido de nuestra voluntad. Ya indicamos que en lugar de preocuparnos de la voluntad, resulta provechoso atender a la autonomía personal, pero cuando se trata de una institución paradigmáticamente moderna como el vínculo contractual, es necesario examinarlo según las intuiciones que lo reconocen como un artefacto humano decisivo de cooperación y coordinación humana. En este sentido, no hay por qué pensar al derecho como una ruptura de la autonomía de los individuos y, bajo 
consideración alguna, suponer que la regulación contractual fractura la autonomía que justifica la fuerza vinculante del contrato moderno.

\subsubsection{Reglas secundarias, autonomía y el vínculo contractual}

Asociando la institución contractual con una concepción moderna acerca del fenómeno jurídico de la cual aquélla es parte representativa, resultaría pertinente compatibilizar el reconocimiento de la autonomía personal como valor normativo que justifica a la fuerza vinculante del contrato, con el resguardo y aseguramiento de su operatividad, desarrollado mediante la intervención legislativa en la contratación contemporánea. Establecer a la autonomía, y no así a la voluntad, como el elemento fundamental de la obligatoriedad contractual, permite robustecer al criterio de justificación sobre la base de las nuevas prácticas contractuales, que atendiendo solo a la voluntad de las partes resultaban problemáticas, pero también contribuye a interpretar al derecho privado de acuerdo a sus raíces ilustradas. Si el derecho privado admite ser tematizado como un sistema jurídico ilustrado, entonces, el estándar normativo de la autonomía constituye el criterio que sostiene la construcción de sus conceptos, instituciones y reglamentación. En lo que sigue, se intentará dar cuenta de esta conexión para defender la propuesta anteriormente esgrimida, según la cual la autonomía personal resulta un candidato idóneo para justificar normativamente la obligatoriedad de la relación contractual.

Según se sugirió al término del apartado 1.3.1.3, el parámetro normativo de la autonomía manifiesta su rendimiento explicativo en el enfoque kantiano sobre la conceptuación de la Ilustración. El abandono de criterios externos a la agencia del ser racional, lo insta a emplear su capacidad de entendimiento para conocer a los distintos objetos de conocimiento, determinando las condiciones teóricas de su posibilidad. El espíritu que motiva al movimiento ilustrado, piensa KANT, responde a la autonomía del individuo expresada en atreverse a pensar por sí mismo ${ }^{115}$. Toda verdad impuesta de manera heterónoma debe ser rechazada por el talante crítico del sujeto ilustrado y su irrenunciable búsqueda del conocimiento a partir de su propia agencia reflexiva. Así, el agente está plenamente dotado de facultades necesarias para examinar y comprender a la realidad, saliendo de su minoría de edad. De modo que de acuerdo a la filosofía kantiana, la imagen ilustrada recepciona la fractura entre los términos de autonomía y heteronomía, adjudicando la cuestión a favor de la primera. Pero la razón que es determinante de nuestra autonomía especulativa, admite diversos usos dotados de ámbitos diferenciados de discrecionalidad.

Si nos situamos en el uso privado de la razón, la capacidad de pensar sobre el mundo se encuentra limitada, porque aquel uso se sigue del cumplimiento de una función o cargo público. En cambio, el uso público de la razón carece de restricciones, siendo utilizado cuando los agentes discuten libremente en escenarios doctos

115 Kant (2009), p. 17. 
sobre el devenir que les aqueja ${ }^{116}$. La racionalidad de un agente, que lo libera de su heterónoma inmadurez, es compatible con la existencia de ciertas limitaciones a su ejercicio. En efecto, al preguntarse si los tiempos de Federico II constituían un período ilustrado, KANT advierte que no era así, pero que efectivamente se trataba de una época de Ilustración, sin perjuicio de las dificultades de los agentes para desenvolver su autonomía ${ }^{117}$. Los ciudadanos bajo su diagnóstico no estaban aún capacitados para pensar por sí mismos y, de ahí, que debían valerse de las reveladoras palabras de Federico el Grande II, según el cual " $\mathrm{i}[r]$ azonad todo lo que queráis y sobre lo que queráis, pero obedeced!" 118 .

Es decir, los ciudadanos pueden emplear y ejercer libremente su uso público de la razón para discutir sobre la mejor regulación o tratamiento jurídico que sea objeto de su interés, pero deben obedecer tales normativas, porque una vez que el pueblo se acostumbre a obedecer, alcanzará el genuino ideal de la autonomía ilustrada. Como se podrá apreciar, nuestro propósito no es formular un alegato a favor de este planteamiento funcional al despotismo ilustrado, sino introducir la profunda vinculación existente entre el derecho privado y la autonomía. Las reglas e instituciones jurídicas que conforman al sistema jurídico privado constituyen las condiciones de posibilidad de la autonomía personal de los individuos. Concebir al sistema jurídico privado en términos de un sistema jurídico ilustrado da cuenta de la vigencia de esta versión no ingenua de la autonomía, compatible y sensible a obligaciones, deberes y restricciones.

Esta clase de autonomía es pertinente de exigírsele a instituciones legales como el contrato ${ }^{119}$. Su diseño permite cristalizar la autonomía normativa de los individuos en base a las relaciones contractuales, facultándolos para otorgarse sus propias reglas jurídicas y, asimismo, interviniendo en aquellas zonas en que la peculiaridad del agente involucrado deviene difícil que pueda manifestar adecuadamente su autonomía. De ahí que ha resultado problemático dar cuenta de las nuevas formas de contratación caracterizadas por un debilitamiento de la voluntad de los contratantes, porque efectivamente puede detectarse con menor claridad la participación de la voluntad de los agentes, pero de ello no se sigue que ocurra lo mismo respecto de su autonomía personal. Si la dogmática privada logra acertar al momento de determinar el fundamento de la fuerza obligatoria del contrato, la reglamentación contemporánea del derecho de los contratos no debería ofrecer obstáculos significativos para su adecuación explicativa.

\footnotetext{
116 KANT (2009), pp. 18-20.

117 Kant (2009), p. 23. Cursivas mías.

${ }^{118}$ KANT (2009), p. 25. Cursivas del original.

119 De acuerdo a Enrique Barros Bourie, "[e]l contrato es el instrumento dinámico de la economía y es la expresión más fuerte de la autonomía en el ámbito estrictamente jurídico”. BARros BouriE, Enrique (2009). "El contrato y el hecho que causa daño como antecedentes de la responsabilidad". En: Estudios de Derecho Civil IV, Jornadas Nacionales de Derecho Civil Olmué 2008, Santiago: Legal Publishing, p. 297.
} 
De igual modo, esto se evidencia en la insistencia de la reflexión jurídica en ubicar a la libertad de las partes como el estándar ineludible para que la obligatoriedad del contrato goce de valor epistémico. La autonomía de la voluntad como principio de la moralidad se encuentra fuertemente relacionada con la libertad. En particular, gracias a esta regla suprema de la ética kantiana, resulta plausible a lo menos teoréticamente presuponer un mundo de noúmenos bajo el cual el ser racional puede pensarse libremente, sin el gobierno de las leyes de la causalidad. Por ende, no es erróneo concebir la legitimidad del vínculo contractual a partir de la libertad. Indudablemente dicha noción es indispensable para un análisis satisfactorio de la fuerza obligatoria del contrato. El yerro pudiere estar en la parcialidad del análisis sobre la noción de libertad, al momento de establecerla como un fundamento de las relaciones jurídicas constituidas en el fenómeno jurídico. El derecho privado no ha obtenido todo el partido teórico que pudiere extraer de las contribuciones esgrimidas desde la reflexión sobre filosofía de la política, demarcando dos entendimientos sobre la libertad. Según se sabe, el contraste conceptual y valorativo exigía reconocer a la libertad negativa y a la libertad positiva ${ }^{120}$. No obstante lo cual, las explicaciones formuladas bajo la dogmática civil suelen asumir que la libertad amparada en nuestras reglas jurídicas privadas corresponde a su sentido negativo, sin cuestionarse cuál de ambas nociones inconmensurables sobre la libertad se encuentra en juego en las distintas normas que la protegen y otras que presuponen su vigencia ${ }^{121}$.

Veamos en qué consisten ambos entendimientos sobre la libertad. La libertad negativa es la que obtiene un sujeto, en tanto ningún hombre ni ningún grupo interfieren en su actividad. Un agente no es libre si otros le impiden hacer lo que podría hacer si no se lo impidieran ${ }^{122}$. Si el ámbito de actividad se reduce al mínimo, la intensidad de la interferencia se constituye en coacción. Los impedimentos constituyen obstáculos para la libertad del agente, mientras más ausencia de interposición, mayor libertad. La libertad negativa es estar libre de que no interfieran en la actividad del ser humano más allá de un límite. Ella implica la ausencia de restricciones a lo que podemos hacer dentro de nuestras capacidades.

En cambio, la libertad positiva "[...] deriva del deseo por parte del individuo de ser su propio dueño" ${ }^{23}$. Se sigue del deseo que su vida y sus decisiones únicamente dependan de sí mismo y no de fuerzas exteriores, como las fuerzas materiales productivas. El agente solo es instrumento de sí mismo, definitivamente es un sujeto

\footnotetext{
${ }^{120}$ BerLin, Isaiah (1974). "Dos conceptos de libertad" [Two Concepts of Liberty]. En: Libertady necesidad en la historia. BaYÓn, Julio (Trad.), Madrid: Revista de Occidente, pp. 133-182.

${ }^{121}$ Un esfuerzo en este sentido, respecto a las libertades en materias propietarias y contractuales, se encuentra en Schapp, Jan (1998). Derecho Civil y Filosofía del Derecho. La Libertad en el derecho. ViLlar Borda, Luis (Trad.), Bogotá: Universidad Externado de Colombia, pp. 55-84.

122 BERLin (1974), p. 137.

123 Berlin (1974), p. 145.
} 
y no objeto. Quiere ser consciente de sí mismo como un ser activo que piensa y que quiere, que tiene responsabilidad por sus propias decisiones y es capaz de explicarlas en función de sus propias ideas y propósitos. Es la libertad para seguir una determinada forma de vida, con una fuerza proactiva que no solo se conforma con la disminución de impedimentos. Es la libertad que agudamente Benjamin CONSTANT denominó de los antiguos.

La escisión entre ambos entendimientos se justifica no solo por sus diferencias conceptuales, sino porque como lo enseñó Isaiah BERLIN, tras ambos conceptos subyacen sistemas valorativos irreconciliables e inconmensurables entre sí ${ }^{124}$. Podemos asociar la pretensión de disminuir toda barrera de heteronomía en la libertad negativa y de realizar efectivamente la autonomía del agente bajo la libertad positiva. Desde luego, si la dogmática civil considera que la libertad cautelada como valor normativo en el sistema jurídico privado se ajusta a los términos negativos de libertad, aquella es necesariamente transgredida cuando existen obstáculos legislativos a su ideal amplitud. Las categorías contractuales que analizamos, por ejemplo, claramente son impedimentos a la libertad negativa de los contratantes. Ahora bien, las conclusiones anteriores son apresuradas ya que no toman en consideración al entendimiento rival de la libertad negativa, esto es, la libertad positiva. Un sistema jurídico privado que procura garantizar la libertad de cada individuo de ser su propio dueño y ceñirse a sus decisiones autónomamente adoptadas, no tiene por qué conceder el punto según el cual las regulaciones legislativas del derecho contractual contemporáneo interrumpen el despliegue de la libertad de los contratantes.

En efecto, y según se ha sugerido, la efectividad de la autonomía de los sujetos se encuentra posibilitada materialmente porque estas regulaciones existen. De acuerdo a lo anterior, un derecho privado sensible a las especificidades de sus partícipes no puede resultar inmune a consideraciones positivas de la libertad. Al sustituir la noción de libertad negativa quizás vigente en un diagnóstico decimonónico de la codificación, por una comprensión positiva de la libertad que se haga cargo activamente de las asimetrías económicas y sociales de los contratantes, el derecho de los contratos abandonará su consuelo de contemplar formalmente a la libertad de los sujetos, comenzando a asegurar el ejercicio material de la libertad de los participantes en el ámbito contractual. Una interpretación de la autonomía personal como la sostenida durante esta sección se encuentra mucho más relacionada a un entendimiento positivo de libertad, que a uno negativo sobre la libertad de los contratantes ${ }^{125}$.

${ }^{124}$ En términos del filósofo de Riga, los entendimientos sobre la libertad “[...] no constituyen dos interpretaciones divergentes de un mismo concepto, sino dos actitudes propiamente divergentes e irreconciliables respecto de la finalidad de la vida”. Véase, BerLin (1974), p. 177.

125 La conjugación entre los conceptos de libertad negativa y positiva bajo el escenario del derecho civil, pudiere construirse recurriendo a las consideraciones kantianas sobre el derecho y la libertad de los arbi- 
Como se podrá apreciar, la propuesta de reformulación de la justificación normativa de la fuerza obligatoria del contrato en términos de autonomía personal, arrojó un cúmulo de consideraciones de segundo orden, es decir, relativas a la identidad del derecho privado. Efectivamente, al examinar un modelo de comprensión internalista sobre el fenómeno jurídico privado, podemos articular una estructura de esta área del ordenamiento jurídico, definida por la autonomía que justifican tanto a sus instituciones y prácticas jurídicas, como a las reglas jurídicas que lo conforman. Enseguida, se examinarán dos grupos de observaciones asociadas a develar la identidad del derecho privado y, a su vez, a clarificar el tipo de reglas jurídicas que componen al fenómeno jurídico privado. Mientras la idea del derecho privado será proveída por las investigaciones de Ernest J. WeINRIB, las funciones que socialmente cumplen las reglas secundarias del ámbito privado, se formularán a partir de las contribuciones efectuadas por H.L.A. HART a la teoría del derecho contemporánea, desde mediados del siglo pasado.

En términos polémicos, WeINRIB proclamó que “[...] el propósito del derecho privado es ser derecho privado" ${ }^{\text {26 }}$. Su afirmación buscaba llamar la atención frente a las propuestas surgidas en las distintas variantes del análisis económico del derecho para identificar en objetivos como la eficiencia económica, la supuesta identidad del derecho privado. Estas perspectivas, que el autor denominó genéricamente como instrumentalismos o externalismos, desatendían la dimensión interna y formal de la estructura del sistema jurídico privado, interpretándolo funcionalmente para cumplir propósitos exógenos, que no son los suyos, sino los emanados del mercado. ¿Cómo podría ayudarnos esa afirmación de WeINRIB? Se pudiere decir que el abandono de las posiciones externalistas del análisis económico del derecho no solo dará cabida a la justificación normativa de la obligatoriedad contractual, sino que se podrá clarificar en qué consiste el derecho privado y cómo su estructura normativa se refleja en la fuerza obligatoria del contrato. Un examen interno y formal de la configuración del derecho privado también sitúa a la autonomía de los participantes al centro de sus preocupaciones.

De acuerdo a WeINRIB, el derecho privado debe entenderse como una experiencia peculiar formulada a partir de formas distintivas de interacción entre los particulares. Por lo tanto, quienes determinan su sentido son quienes participan bajo su marco y prácticas institucionales. La comprensión del fenómeno jurídico se encuentra sujeta a un análisis interno desarrollado desde el reconocimiento de las prácticas del lenguaje y del razonamiento empleado bajo el contexto de las re-

trios, establecidas en Kant, Immanuel (1989). La Metafísica de las Costumbres [Metaphysik der Sitten]. Cortina O., Adela y Conill S., Jesús (Trad.), Madrid: Tecnos, pp. 37-43. La libertad negativa efectuaría una tarea de delimitación, determinando negativamente esferas de libertad, cuya función radica en que los "[...] beneficiados realicen una libertad positiva en los espacios de libertad protegidos". Véase SchAPp (1998), pp. 63 y ss. De ahí que la protección jurídica de la relación obligatoria fijada por las partes admite equipararse con la autonomía privada en su sentido positivo.

126 WeINRIB (2012), p. 5. 
laciones entre particulares. En este sentido, el tipo de interacción que se produce bajo el derecho privado siempre demuestra dimensiones directas de contrariedad o ajustarse a un régimen adversarial ${ }^{127}$. Aquello ocurre, por ejemplo, si hablamos de contratos en que nuestra experiencia práctica demuestra que concurre un sujeto que ha incumplido sus prestaciones y otro que correlativamente reclama el cumplimiento y la reparación de los perjuicios derivados de la infracción contractual. Además, si nos situamos en los derechos reales, existe un dueño a quien cualquier otro le ha privado o perturbado total o parcialmente en su dominio. Finalmente, en el ámbito de la responsabilidad civil extracontractual, se presenta una víctima que ha sido dañada injustamente producto de una interacción espontánea, reclamando la reparación del daño provocado por el agente dañoso ${ }^{128}$.

El esqueleto bajo el cual se construye el derecho privado está trazado a través de dos elementos. Uno de carácter institucional y otro de índole conceptual ${ }^{129}$. Mientras la institucionalidad del fenómeno jurídico privado se expresa mediante mecanismos de adjudicación sobre el conjunto de facultades, derechos y deberes correlativos que le corresponden a los sujetos de una relación jurídica privada, su esfera conceptual alude a la correlatividad característica de la relación privada, porque ahí donde existe una facultad o derecho subjetivo existe un deber o una carga correlativa. Esta estructura interna brinda inteligibilidad al sistema jurídico privado y permite que el sentido de las prácticas de interacción entre demandante y demandado corresponda al significado que para los participantes de las prácticas jurídico-privadas estas posean. Así, el sistema de clausura es coherente, dado que el derecho privado solo puede ser aquello que por su estructura interna está condicionado a ser.

Un aspecto significativo que es posible aprovechar de la propuesta internalista de WeINRIB, radica en su sugerencia de que la dimensión estructural define lo que puede llegar a ser el derecho privado. Si es correcto lo sostenido con anterioridad, en orden a identificar al sistema jurídico privado mediante su sustantivo compromiso con la noción de autonomía, la dimensión formal e institucional de esta rama del ordenamiento jurídico debiere atender a estas consideraciones. El derecho privado

\footnotetext{
${ }^{127}$ Este énfasis para comprender al derecho privado en términos de las relaciones de interacción directa que sostienen los participantes de las prácticas jurídicas privadas, en base a sus derechos privados para accionar, también es compartido en ZiPURSKY (2004), pp. 632-636.

${ }^{128}$ Acerca de una fundamentación de la responsabilidad en términos de los contextos de participación bajo los cuales se sitúan los agentes moralmente responsables de sus acciones, es decir, respecto de los cuales resulta pertinente experimentar emociones morales como el resentimiento y la gratitud, véase PEREIRA FredES, Esteban (2010a). "Contextos de participación como fundamento de la responsabilidad”. En: Causas perdidas. Ensayos de filosofía jurídica, política y moral. Santiago: Catalonia, pp. 307-331. Un cuidado examen sobre la conexión entre la responsabilidad civil extracontractual y las demandas de justicia correctiva y distributiva en Pino Emhart, Alberto (2013). "Entre reparación y distribución. La responsabilidad civil extracontractual como mecanismo de distribución de infortunios". Revista Chilena de Derecho Privado, No 21, pp. 89-135.

129 Weinrib (2012), pp. 9-10.
} 
moderno surgió bajo el alero de una filosofía de la moral apelativa a la autonomía personal de los individuos, frente a los criterios de corrección heterónomamente impuestos. De modo que un sistema jurídico privado renuncia a propósitos ajenos a sus prácticas internas y sus relaciones de interacción evidencian modalidades de autonomía de los agentes. Su agencia está involucrada en el fenómeno jurídico privado, tanto en la constitución de las relaciones jurídicas, como en la protección que el derecho les brinda. La estructura interna tiende a la consolidación del valor de la autonomía en las relaciones entre los agentes. El derecho privado es autonomía y, siguiendo a WeINRIB, si no puede ser otra cosa distinta, el derecho privado solo puede ser autonomía.

Esta conexión entre la estructura interna de interacción entre particulares distintiva del derecho privado y su profunda apelación por la autonomía de los agentes, puede clarificarse en mayor medida, si atendemos al tipo de reglas jurídicas que componen dicha estructura formal. Para tales efectos, se utilizará la noción de HART sobre las reglas secundarias que confieren potestades a los particulares. Dicha reglas, según se sostendrá, reflejan la dimensión interna de autonomía respecto a la cual corresponde entender al derecho privado y, por consiguiente, al derecho de los contratos. La fuerza obligatoria del vínculo contractual constituye una esfera particular de lo que el derecho privado es y en cuyos términos se deben emprender sus tareas justificativas ${ }^{130}$.

De acuerdo a HART, un sistema jurídico propiamente tal debe renunciar a las pretensiones del monismo en teoría del derecho reflejadas en los modelos imperativistas de Jeremy BENTHAM y John Austin, formulados a mediados del siglo XIX ${ }^{131}$. Dicho monismo se manifestaba bajo dos puntos de vista: la identidad de las reglas jurídicas y las perspectivas bajo las cuales debe examinarse al fenómeno jurídico. Desde el primer orden de observaciones, el monismo normativo consideraba que el ordenamiento jurídico únicamente se encuentra conformado por reglas primarias que imponen obligaciones a los sujetos y establecen sanciones frente a sus infracciones. Estas reglas son de carácter sancionatorio y su imagen corresponde a las normas pertenecientes al Derecho Penal. A su vez, bajo el segundo orden de consideraciones, el monismo sugería que resulta suficiente concebir al fenómeno

\footnotetext{
${ }^{130}$ Esta cuestión resulta relevante para propósitos de otorgar coherencia al sistema jurídico privado, ya que la coherencia es una propiedad interna al sistema que se obtiene según la estructura, conceptos, instituciones y reglas jurídicas, bajo las cuales se relacionan los participantes en la mayoría de sus transacciones. De acuerdo a Weinrib, "Coherencia significa un modo de inteligibilidad que es interno a la relación entre las partes de un todo integrado”. Véase, WeInRIB (2012), p. 14.

${ }^{131}$ Bajo el contexto de la tradición analítica de la filosofía del derecho, existen distintas tensiones entre estrategias monistas de carácter formal o empíricas y aquellas sensibles a la diversidad de las prácticas sociales, para comprender al fenómeno jurídico. Dichas posiciones se manifiestan en la distinción entre las investigaciones sobre el concepto de derecho y la explicación de la naturaleza del derecho, como desafíos de la teoría del derecho contemporánea. Al respecto, véase Pereira Fredes, Esteban (2012). "La teoría del derecho como posibilidad. Reflexiones sobre la naturaleza y el concepto de derecho". Revista de Estudios de la Justicia, No 17, pp. 83-104.
} 
jurídico adoptando un punto de vista externo a las prácticas jurídicas, relativo a aquella posición que desarrolla un observador quien no acepta a las reglas jurídicas como pautas de comportamiento. Sería posible comprender al derecho sin ser, en estricto rigor, parte de él.

El oxoniense rechazó ambas dimensiones monistas, adaptándolas a las exigencias de la diversidad característica del fenómeno jurídico. Respecto al monismo ontológico, su propuesta no lograba dar cuenta de la diversidad de reglas existentes bajo un sistema jurídico robusto. Aquello se deriva de la tesis según la cual no solo existen reglas primarias que imponen obligaciones y prescriben castigos para el evento que fueren incumplidas, sino que también se advierten reglas secundarias que cumplen una función socialmente distinta a las primarias. El carácter de dichas reglas contrasta radicalmente con la imagen punitiva de las primarias, ya que confieren potestades públicas o privadas. Se trata de reglas potestativas que en lugar de obligar, facultan a los agentes a conseguir estados de cosas deseados mediante la observancia de ciertos requisitos o procedimientos. En términos de HART, dichas reglas "[...] acuerdan a los particulares facilidades para llevar a cabo sus deseos, al otorgarles potestades para crear, mediante ciertos procedimientos específicos y bajo ciertas condiciones, estructuras de facultades y deberes dentro del cuadro coercitivo del derecho"132. De ahí que un modelo monista en su mejor versión posible, únicamente lograría explicar a las reglas del Derecho Penal, sin cubrir al derecho privado. Si se tuviera que descomponer la estructura interna del sistema jurídico privado, se obtendría un número inagotable de reglas secundarias potestativas, establecidas en las distintas temáticas del derecho privado, tales como propiedad, obligaciones, contratos y relaciones familiares. De un modo u otro, la justificación de esta estructura interna descansa en el fundamento que antes hemos sugerido para interpretar al derecho privado; a saber, la autonomía.

Las reglas que confieren potestades constituyen el mecanismo normativo mediante el cual los agentes pueden desplegar su autonomía en los asuntos jurídicos y aquello "[...] es uno de los grandes aportes del derecho a la vida social [...]"133. Desde la esfera de las instituciones, por ejemplo, el contrato expresa dimensiones de autonomía para los particulares en virtud de las cuales pueden generar núcleos de obligaciones y garantizar la vigencia obligatoria de estos vínculos. Mediante el cumplimiento de los elementos establecidos en reglas potestativas como las brindadas por nuestro codificador en los artículos 1445 y 1438, los individuos se encuentran facultados para generar autónomamente relaciones obligatorias resguardadas por la autoridad de los términos del artículo 1545 del Código Civil. Si HART está en lo correcto, no es trivial la asociación de las reglas secundarias al derecho privado, porque el fundamento de aquellas radica precisamente en garan-

\footnotetext{
${ }^{132}$ Hart, H.L.A. (1963). El Concepto de Derecho [The Concept of Law]. Carrió, Genaro R. (Trad.), Buenos Aires: Abeledo-Perrot, p. 35. Cursivas del original.

${ }^{133}$ Hart (1963), p. 35.
} 
tizar el valor normativo de la autonomía de los agentes y estas reglas se encuentran al servicio de la operatividad de esta justificación. El problema de la justificación normativa de la relación contractual se resuelve cuando situamos nuestra atención en el tipo de reglas que conforman al sistema jurídico privado y transparentamos su sistemático compromiso con la autonomía personal.

Piénsese que la interpretación sostenida al comienzo del apartado anterior de este trabajo, relativa a recuperar el rol que jugó la autonomía en la formulación del derecho privado bajo el paradigma del iluminismo, contribuye a tematizar las reglas jurídicas que lo componen bajo el mismo estándar normativo. Del modo en que lo sugería KANT, las esferas de autonomía normativa reconocen la pertinencia de exigencias vinculadas a la observancia y satisfacción de razones formuladas de un modo institucionalizado, que lejos de interrumpir la agencia de los individuos, procuran asegurar y encauzarla de manera que las reglas jurídico-privadas no sean solo facultades formales, sino que correspondan a modalidades institucionalizadas sobre la autonomía personal, habiendo sido contempladas bajo el sistema jurídico privado.

Finalmente, acerca del déficit de diferenciación de las perspectivas desde las cuales es posible estudiar al fenómeno jurídico, HART consideró que bajo un punto de vista externo no sería posible obtener una explicación satisfactoria del derecho. Podría entenderse a lo jurídico en términos de signos, datos o antecedentes a partir de los cuales un observador que se limita a describir el fenómeno jurídico a partir de regularidades, podría predecir la aplicación de posibles castigos. Dados ciertos comportamientos, predice la aplicación de consecuencias deseadas o indeseadas, según se trate de la respectiva conducta. Pero esta explicación no puede formularse de modo alguno en términos de reglas jurídicas, porque las reglas jurídicas constituyen prácticas sociales, es decir, que no pueden ser genuinamente comprendidas sin considerar el significado que representa para los participantes de dicha práctica jurídica ${ }^{134}$. De modo que los participantes de una práctica social como la jurídica despliegan una actitud crítico-reflexiva respecto de las distintas reglas jurídicas que la definen. Aquellos adoptan un punto de vista interno sobre las reglas del derecho porque las aceptan, es decir, "[...] usan las reglas como criterios o pautas para valorar su conducta y la de los demás”"135. Es decir, aceptan a la regla jurídica como guía de la propia conducta. Desde WiTTGENSTEIN, seguir una regla importa una práctica social desplegada por parte de una determinada forma de vida ${ }^{136}$. Y solo hay sistema jurídico ahí donde resida la aceptación de las reglas por parte de sus partícipes.

\footnotetext{
${ }^{134}$ Hart (1963), pp. 99-123.

135 Hart (1963), p. 122.

136 Para el seguimiento de las reglas como prácticas, puede consultarse WiTtGenstein, Ludwig (1998). Investigaciones Filosóficas [Philosophische Untersuchungen]. GarCíA SuÁrEZ, Alfonso y MoulinEs, Ulises (Trad.), Barcelona: Crítica, $\$ 137-242$. Sobre la inexistencia de lenguajes privados, porque no es posible seguir privadamente una regla, véase $\$ 243-315$.
} 
Según lo indicamos, en WeINRIB se concebía que buena parte de la estructura del derecho privado pudiera develarse al poner nuestro acento en las prácticas sociales de interacción que se producen entre las partes. Dichas prácticas fomentan la autonomía de los agentes y las reglas jurídicas secundarias, materializan formalmente sus pretensiones mediante la observancia de procedimientos para obtener estados de cosas deseados, facultándolos para satisfacer sus planes individuales de vida. Ocurre que esta nueva herramienta conceptual asociada a la perspectiva interna de las reglas jurídicas, sugiere que detrás de estas subyacen prácticas sociales, cuyo mérito normativo es aceptado por sus participantes. De modo que una comprensión sobre las reglas jurídicas no puede desplazar el significado que estas representan para quienes de ellas participan. ¿Tiene alguna particularidad el ámbito contractual? Desde luego que no presenta diferencias sustantivas. Pero la apelación a un punto de vista interno de las prácticas contractuales insta a determinar qué significa para los participantes de una relación contractual, una regla jurídica que consagre la fuerza obligatoria del contrato. De seguro los partícipes de la práctica contractual aceptan al artículo 1545 del texto de Bello como una genuina regla jurídica, la cuestión a determinar radica en evidenciar las razones de su aceptación.

¿Por qué los contratantes aceptan la obligatoriedad del vínculo contractual? Si el derecho constituye un conjunto de prácticas sociales determinadas por la aceptación de sus participantes, una adecuada comprensión de la regla secundaria prevista en el artículo 1545 requiere necesariamente dar cuenta que los contratantes no la aceptan como una razón excluyente para sus acciones, sino porque promueve un estándar normativo al cual adhieren como pauta de comportamiento. Este criterio no es otro que la autonomía que dicha regla brinda a los contratantes en sus relaciones particulares. Negar la vigencia de la regla que consagra el efecto obligatorio es infringir la autonomía del propio contratante y la agencia de los demás participantes de las prácticas contractuales. Desde un punto de vista interno de la regla contractual, no encontramos un desacuerdo profundo acerca de lo que para ellos significa la ley del contrato ${ }^{137}$. Solo certificamos la coherencia del derecho privado en su conjunto hacia las exigencias de la autonomía personal y, asimismo, la materialización de aquel ideal que en particular las reglas jurídicas contractuales permiten en los vínculos interpersonales de cooperación.

Si las consideraciones anteriores fueren correctas, la legitimación de la obligatoriedad del contrato se encuentra asociada a la identidad del derecho privado, en torno a su apelación germinal a la autonomía personal y rechazo hacia la heteronomía. El derecho privado es, en buena medida, autonomía. Y aquello se conserva

\footnotetext{
137 Respecto a la construcción de la regla contractual, Álvaro Vidal Olivares ha sostenido que esta preocupación se traduce en dos cuestiones correlativas. Por una parte, determinar ¿̇cómo se construye la regla contractual? Y, por otra, clarificar ¿cuál es la regulación a la que se someterá la conducta de las partes de la relación jurídico-contractual correspondiente? Sobre lo anterior, véase VidAL Olivares, Álvaro (2000). "La construcción de la regla contractual en el derecho civil de los contratos". Revista de Derecho, Pontificia Universidad Católica de Valparaíso, Vol. XXI, pp. 209-227.
} 
aun cuando se detecte una mayor intervención legislativa en las relaciones jurídicas. Pues su estructura e instituciones reflejan una versión madura y no ingenua de esta noción, admitiendo en ella la pertinencia de reglamentaciones tendientes a establecer requisitos o procedimientos para disfrutar de los estados de cosas a los cuales las reglas jurídico-privadas facultan a alcanzar. Una regla como la establecida en el artículo 1545 del Código Civil es aceptada por los participantes del ámbito contractual, porque les sugiere pautas normativas de interacción que estiman razonables para sus planes personales de vida. La autonomía personal involucrada en una regla que establezca la fuerza vinculante del contrato no constituye sino una forma institucionalizada de reconocimiento del respeto del sistema jurídico privado al despliegue individual de sus participantes. Y de ahí que sea razonable aceptarla como regla jurídica. De otro modo, habría que renunciar a la autonomía que el derecho privado nos pretende otorgar.

\section{CONCLUSIONES}

El contrato constituye una de las instituciones de mayor significación en la construcción de la realidad social. Sin embargo, el problema relativo a la justificación de la obligatoriedad del vínculo contractual no es un terreno pacífico, dado que si bien en los sistemas jurídicos privados existe una regla contractual como la establecida en el artículo 1545 del Código Civil chileno, la dogmática civil no expresa un acuerdo en la necesidad de justificar su presencia en términos valorativos, o incluso rechazando que la fuerza obligatoria del contrato se trate de una cuestión normativa, que requiera un esfuerzo mayor a un examen meramente descriptivo de la regla jurídica que la consagra.

Existen distintos esquemas de comprensión en disputa para dar cuenta del problema de la justificación de la fuerza obligatoria del contrato. Por una parte, modelos normativos que afirman la necesidad de develar cuál criterio de corrección moral otorga las mejores razones para aceptar la vigencia de una regla jurídica contractual. Por otra, modelos no-normativos que no obstante aceptan la relevancia de la existencia de una regla contractual que sostenga la fuerza vinculante, rechazan que aquella deba legitimarse en términos valorativos, bastando un examen descriptivo asociado a las nociones de eficiencia económica o a través de las condiciones formales de imputación de consecuencias jurídicas frente a la verificación de supuestos factuales.

De manera tradicional se ha aceptado el dogma de la autonomía de la voluntad para justificar la obligatoriedad de la relación contractual, bajo el contexto del derecho privado. De modo tal que los contratos deben ser incondicionadamente observados, ya que constituyen relaciones jurídicas generadas por la manifestación libre y consentida de la voluntad de los contratantes. Dado que los contratos se fundamentan en la voluntad de las partes, como elemento generador de obligaciones, estas deben ser necesariamente cumplidas. Este paradigma fue asumido por 
el movimiento codificador y buena parte de la incipiente reflexión jurídica sobre la filosofía del derecho privado.

La tesis del contrato como promesa esgrimida por Charles FrIED admite ser reconocida como la propuesta de mayor influencia entre los modelos normativos de justificación de la fuerza vinculante de la relación contractual. Un contrato obliga a sus contratantes porque lleva envuelta una promesa moral de cumplimiento. Cuando un contratante promete una determinada actuación futura, genera legítimas expectativas de comportamiento en su contraparte. Si aquel promitente infringe la estipulación pactada, traiciona la confianza que en él depositó el contratante depositario de su promesa contractual. La promesa moral justifica normativamente la obligatoriedad del contrato.

El marco contractual contemporáneo consiste en el conjunto de principios y reglas jurídicas que se han implementado desde inicios del siglo XX, en orden a incrementar la intervención del órgano legislativo en las relaciones contractuales privadas. A su vez, en forma consecuencial, la voluntad de las partes ha sido situada a un aparente rol secundario en el derecho de los contratos, debilitando progresivamente la tesis según la cual los contratos obligan en base a la voluntad libremente manifestada que justificó el nacimiento de sus obligaciones. Aquello se refleja en la inserción legislativa de categorías contractuales en los sistemas jurídicos privados, de acuerdo a las cuales es posible prescindir de la voluntad de las partes para concluir una relación contractual o bien para determinar el contenido normativo que lo gobierna.

El desafío de la voluntad, como fundamento de la obligatoriedad del vínculo contractual, no es tanto acreditar su supervivencia, como admitir la necesidad de su reformulación bajo este nuevo estado de cosas. Los modelos de comprensión asociados a la voluntad de las partes descansaron en una visión decimonónica de la voluntad, presuponiendo erróneamente la simetría social y económica de los agentes. Dado que las prácticas contractuales develaron los profundos desequilibrios entre el poder negociador de los distintos contratantes, esta noción de la voluntad se expuso a un sinnúmero de críticas. Un yerro de la dogmática civil que abrazó el principio de la autonomía de la voluntad radica en adjudicar el mérito epistémico a la voluntad, descuidando el potencial justificativo de la noción de autonomía.

La noción de autonomía fue el prisma bajo el cual se trazó toda genuina obligación bajo el movimiento ilustrado y, a su vez, en la filosofía moral de raíces kantianas. Desde su formulación germinal, la autonomía se consideró como un estándar normativo compatible con dimensiones de intervención, cuando las razones que la justificaban reclamaban precisamente la implementación de mecanismos destinados a asegurar el efectivo despliegue de la autonomía personal de agentes, quienes en su particularidad de circunstancias no podrían verdaderamente hacerlo. La voluntad no constituía un valor normativo por sí misma, solo cuando dicha voluntad devenía autónoma correspondía reconocerla como la justificación de las obligaciones que de ella emanaban. 
El esquema de Dori Kimel ha hecho justicia a la tesis según la cual atender a la noción de autonomía puede resultar satisfactorio para reafirmar la pertinencia de la autonomía personal de los contratantes, frente a un régimen contractual caracterizado por una mayor intervención del legislador y bajo las pretensiones de neutralidad de un sistema jurídico de raigambre liberal. La legitimidad de la fuerza obligatoria del contrato descansa en el respeto del contratante a su autonomía ejercida en los asuntos privados, así como también a la autonomía que su contraparte en el contrato desplegó al momento de suscribir la relación jurídica que los une. La lectura de KimeL se muestra más cercana al pensamiento de Immanuel KANT y compatible a las contemporáneas exigencias sobre regulación contractual.

El contrato y su fuerza vinculante son nociones cuya comprensión se ajusta a una perspectiva moderna del fenómeno jurídico. Bajo esta aproximación, el derecho y sus instituciones son creaciones artificiales de la agencia colectiva de sus intervinientes y no elementos tributarios de un orden natural. Su justificación se transparenta al situar nuestra atención en la función que los individuos sostienen que aquellas debieren cumplir. El carácter institucional del contrato determina la necesidad de justificar su existencia y proveer de razones de acuerdo a las cuales podemos aceptar que el cumplimiento de las relaciones contractuales resulte obligatorio para los contratantes. Si bien una regla jurídica como la prescrita en el artículo 1545 del Código Civil puede ser considerada como una razón excluyente para la acción de los contratantes, su formulación moderna exige detenerse a legitimar normativamente su vigencia, develando el valor que está en juego en sus términos, volviendo razonable a la regla contractual. Dado que el contrato no puede ser comprendido como un hecho natural de interés trivial, la fuerza con que aquel vincula a sus contratantes, tampoco podría estimársele de tal modo.

La noción de voluntad no debe ser abandonada del derecho contractual contemporáneo, pero sí admite ser reformulada en términos de autonomía personal. Aceptar a la autonomía como el valor normativo de la obligatoriedad contractual contribuye a develar el sentido del derecho privado como un cúmulo de mecanismos destinados a la institucionalización de la autonomía de los agentes en sus relaciones de cooperación e intercambio. Las raíces intelectuales del término, extraídas desde las empresas de KANT y ROUSSEAU, brindan dimensiones exploratorias relevantes para desplazar a la voluntad y centrarnos en la autonomía como fundamento de las obligaciones contractuales. Aquella no solo es compatible con modalidades de intervención que se justifican para garantizar el genuino despliegue autónomo de agentes, que presentan dificultades bajo el escenario contractual. De igual manera, permite interpretar que estas intervenciones legislativas, como las categorías contractuales, se legitiman precisamente porque los individuos no están situados en las posiciones contractuales, hipotéticamente simétricas para expresar su autonomía como ideal regulativo del autogobierno en sus relaciones obligatorias. 
Si se trata de la vinculación persistentemente esgrimida por la dogmática civil entre los términos de voluntad y libertad, como elementos decisivos de las relaciones jurídicas obligatorias, no existe una relación analítica entre ambas nociones. La voluntad también se encuentra expuesta a dimensiones de heteronomía, que obstaculizan su libre desarrollo. Del mismo modo, pese a que la reflexión jurídicoprivada no se ha detenido a evaluar cuál entendimiento de la libertad se encuentra consagrado en las reglas jurídicas, aceptando su correspondencia a un concepto negativo de libertad, ha extraviado el rendimiento explicativo que otorgaría la libertad en su sentido positivo, como el valor normativo que resguardan las distintas instituciones y prácticas del fenómeno jurídico privado. Esta comprensión de la libertad, asociada a la autonomía de los agentes, se muestra teóricamente compatible con dimensiones de intervención implementadas para garantizar el efectivo despliegue de la autonomía personal en las relaciones jurídicas.

La autonomía permite comprender a la estructura interna del fenómeno jurídico privado y las reglas que lo conforman. Desde las contribuciones de Ernest J. WeINRIB, el derecho privado solo puede ser derecho privado. El desafío es determinar en qué consiste, entonces, el sistema jurídico privado desde una perspectiva interna. Se sostiene que aquel se encuentra definido por su apelación a la autonomía personal de los agentes, estableciendo tanto instituciones como prácticas que no solo autorizan a expresiones de su agencia individual, sino también procuran garantizar efectivamente su pertinencia en los asuntos privados. Se debe rechazar la adscripción de propósitos exógenos al derecho privado, como lo sería la eficiencia económica, porque esta noción no es parte del sistema jurídico privado. En cambio, si el derecho privado admite ser entendido como un sistema jurídico ilustrado, corresponde interpretarse en términos de su compromiso con la autonomía.

Las reglas jurídicas que componen la estructura interna del derecho privado son, bajo la nomenclatura de H.L.A. HART, reglas secundarias potestativas. Estas reglas jurídicas se caracterizan porque, a diferencia de las reglas que gobiernan el ámbito jurídico público, no imponen obligaciones a los individuos y sanciones frente su eventual infracción, sino que otorgan facultades para facilitar el despliegue de su agencia autónoma. La vida social se enfrenta a un cúmulo de transformaciones efectuadas mediante instituciones sociales, generadas a partir de reglas jurídicas que confieren potestades. Gracias a estas reglas jurídicas, el sistema jurídico privado ofrece mecanismos de institucionalización de la autonomía de los participantes en sus prácticas jurídicas privadas.

Tras el problema de la fuerza obligatoria del contrato subyacen cuestiones de segundo orden, relativas a determinar qué es el derecho privado al cual la institución contractual pertenece. Existe una coherencia interna entre ambas consideraciones, ya que aquellas responden a exigencias normativas sobre la autonomía personal. El fenómeno jurídico constituye un cúmulo de prácticas sociales cuyo significado corresponde al sentido que sus partícipes le atribuyen. De modo que 
la fuerza obligatoria de la relación contractual significa para los contratantes el aseguramiento de su despliegue autónomo en sus relaciones jurídicas. El derecho privado es, sustantiva y analógicamente a las prácticas contractuales, autonomía.

Si el propósito es determinar por qué es razonable la existencia de una regla contractual establecida en los términos del artículo 1545 de nuestro Código Civil, una adecuada comprensión abrazaría un punto de vista interno de las prácticas contractuales que dicha normativa gobierna. Los participantes aceptan la fuerza obligatoria de dicha regla jurídica porque consideran que aquella provee de razones normativas para adoptar los comportamientos de observancia contractual que aquella prescribe. Dicha regla jurídica, lejos de constituir una razón exclusionaria para sus comportamientos, es aceptada como obligatoria, ya que es estimada como una pauta legítima de sus comportamientos autónomos. Estas razones no hay que buscarlas en algo distinto de lo que el derecho privado, como mecanismo institucionalizado de la autonomía de los agentes, pretende ser. De un modo u otro, la fuerza vinculante del contrato se justifica adecuadamente en la autonomía de sus participantes, porque son aquellos los encargados de definir las razones bajo las cuales aceptan su vigencia. La autonomía se ofrece como el estándar normativo que justifica la complejidad social del derecho privado en general y, a su vez, la legitimidad de la existencia y fuerza vinculante de su institución más decisiva, es decir, el contrato.

\section{BIBLIOGRAFÍA CITADA}

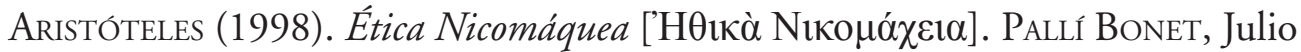
(Trad.), Madrid: Gredos.

AтIYAн, P. S. (1979). The rise and fall of freedom of contract. Oxford: Oxford University Press.

AтіYAн, P. S. (1986). "Form and Substance in Contract Law". En: Essays on Contract. Oxford: Clarendon Press, pp. 93-120.

Austin, J. L. (1999). "Emisiones realizativas" [Performative utterances]. En: La buisqueda del significado, García SuÁrez, Alfonso (Trad.), Madrid: Tecnos, pp. 419-434.

BaGCHI, Aditi (2011). "Separating contract and promise". Florida State University Law Review, Vol. 38, No 709, pp. 710-758.

Barcia Lehmann, Rodrigo (2004). "Los efectos de las obligaciones desde la perspectiva del análisis económico”. En: Cuadernos de Análisis Jurídicos: Colección de Derecho Privado, Tomo I, Temas de Responsabilidad Civil. Santiago: Ediciones Universidad Diego Portales, pp. 127-167.

BARCia LeHMANN, Rodrigo (2005). “¿Es posible construir la teoría general del contrato desde la excepción: la revisión judicial del contrato?”. En: Sesquicentenario del Código Civil de Andrés Bello: Pasado, Presente y Futuro de la Codificación, Tomo I. Santiago: LexisNexis, pp. 685-719. 
Barros Bourie, Enrique (2009). "El contrato y el hecho que causa daño como antecedentes de la responsabilidad". En: Estudios de Derecho Civil IV, Jornadas Nacionales de Derecho Civil, Olmué 2008, Santiago: LegalPublishing, pp. 297-313.

Benson, Peter (2010). "Contract". En: A Companion to Philosophy of Law and Legal Theory, Oxford: Blackwell, pp. 29-63.

BerLin, Isaiah (1974). "Dos conceptos de libertad" [Two Concepts of Liberty]. En: Libertad y necesidad en la historia, BAYÓN, Julio (Trad.), Madrid: Revista de Occidente, pp. 133-182.

Bix, Brian H. (2008). "Contract rights and remedies, and the divergence between law and morality”. Ratio Juris, Vol. 21, No 2, pp. 194-211.

Bix, Brian H. (2012). Contract Law. Rules, Theory, and Context. Cambridge: Cambridge University Press.

Claro Solar, Luis (1935). Explicaciones de Derecho Civil Chileno y Comparado. Tomo IX. Santiago de Chile: Nascimento.

Cooter, Robert y Ulen, Thomas (1998). Derecho y Economía [Law and Economics]. Corrales, Carlos Floriano (Trad.), México D.F.: Fondo de Cultura Económica.

Corral Talciani, Hernán (2002). "La definición del contrato en el Código Civil chileno y su recepción doctrinal. Comparación con el sistema francés”. En: Cuadernos de Extensión Jurídica, No 6, pp. 69-97.

DaGan, Hanoch (2008). "The Limited Autonomy of Private Law”. The American Journal of Comparative Law, Vol. 56, No 3, pp. 809-833.

Dell'Aquila, Enrico (2001). El Contrato en Derecho Inglés. Tomo I. Elementos del contrato y vicios de la voluntad. Barcelona: PPU.

Detmold, M. J. (1989). "Law as Practical Reason". The Cambridge Law Journal, Vol. 48, No 3, pp. 436-471.

FERRY, Luigi (2001). La autonomía privada [L'autonomia privata]. MENDIZÁBAL, Luis Sancho (Trad.), Granada: Comares.

Figueroa, María Angélica (1982). "La codificación civil chilena y la estructuración de un sistema jurídico legalista”. En: Andrés Bello y el Derecho. Santiago: Universidad de Chile, pp. 77-104.

Fried, Charles (1988). ¿Es posible la libertad? En: Libertad, Igualdad y Derecho: Las conferencias Tanner sobre filosofía moral, Barcelona: Ariel.

FrIED, Charles (1996). La obligación contractual. El contrato como promesa [Contract as Promise: A Theory of Contractual Obligation]. Ruíz-Tagle Vial, Pablo (Trad.), Santiago: Editorial Jurídica de Chile.

Gauthier, David (2000). La moral por acuerdo [Morals by Agreement]. BIXIO, Alcira (Trad.), Barcelona: Gedisa.

GeHlen, Arnold (1993). Antropología filosófica: del encuentro y descubrimiento del hombre por si mismo [Man: His Nature and Place in the World]. Cienfuegos W., Carmen (Trad.), Barcelona: Paidós. 
Gordley, James (1991). The Philosophical Origins of Modern Contract Doctrine. Oxford: Clarendon Press.

Gordley, James (2006). Foundations of Private Law. Property, tort, contract, unjust enrichment. Oxford: Oxford University Press.

Hart, H.L.A. (1963). El Concepto de Derecho [The Concept of Law]. Carrió, Genaro R. (Trad.), Buenos Aires: Abeledo-Perrot.

HobBes, Thomas (1992). Leviatán, o la materia, forma y poder de una república eclesiástica y civil [Leviathan, or The Matter, Form and Power of a Commonwealth, Ecclesiastical and Civil]. Sánchez Sarto, Manuel (Trad.), México D.F.: Fondo de Cultura Económica.

Kant, Immanuel (1989). La Metafísica de las Costumbres [Metaphysik der Sitten]. Cortina O., Adela y Conill S., Jesús (Trad.), Madrid: Tecnos.

Kant, Immanuel (2000). Crítica de la Razón Práctica [Kritik der praktischen Vernunft]. Aramayo, Roberto R. (Trad.), Madrid: Alianza.

KanT, Immanuel (2005).Fundamentación para una Metafísica de las Costumbres [Grundlegung zur Metaphysik der Sitten]. AramaYo, Roberto R. (Trad.), Madrid: Alianza.

KANT, Immanuel (2009). “Respuesta a la pregunta: ¿Qué es Ilustración?” [Beantwortung der Frage: Was ist Aufklärung?]. En: ¿Qué es la Ilustración? MaESTRE, Agapito y Romagosa, José (Trad.), Madrid: Tecnos, pp. 17-29.

Kelsen, Hans (1982). Teoría Pura del Derecho [Reine Rechtslehre]. Vernengo, Roberto J. (Trad.), México D.F.: UNAM.

Kimel, Dori (2003). From Promise to Contract: Towards a Liberal Theory of Contract. Oxford: Hart Publishing.

KImEL, Dori (2007). "The choice of paradigm for theory of contract: reflections on the relational model". Oxford Journal of Legal Studies, Vol. 27, No 2, pp. 233-255.

Kinsella, N. Stephan (2003). "A libertarian theory of contract: title transfer, binding promises, and inalienability". Journal of Libertarian Studies, Vol. 17, No 2, spring, pp. 11-37.

López Santa María, Jorge (2010). Los Contratos. Parte General. Santiago: Editorial Jurídica de Chile.

Lucy, William (2007). Philosophy of Private Law. Oxford: Oxford University Press.

Maccormick, Neil (2011). Instituciones del Derecho [Institutions of Law]. ATria, Fernando y Tschorne, Samuel (Trad.), Madrid: Marcial Pons.

MCKendrick, Ewan (2007). Contract Law. London: Palgrave Macmillan.

Mill, John Stuart (2007). El Utilitarismo [Utilitarianism]. GuISÁN, Esperanza (Trad.), Madrid: Alianza.

Momberg Uribe, Rodrigo (2010). “Teoría de la imprevisión: la necesidad de su urgente revisión en Chile”. Revista Chilena de Derecho Privado, No 15, pp. 29-64. 
Ogus, Anthony y Van Boom, Willem H. (Eds.) (2011). Juxtaposing Autonomy and Paternalism in Private Law. Oxford: Hart Publishing.

O'Sullivan, Janet e Hilliard, Jonathan (2012). The Law of Contract. Oxford: Oxford University Press.

Peña González, Carlos (1995). "Los desafíos actuales del paradigma del Derecho Civil”. Estudios Públicos, No 60, pp. 327-348.

Peñailillo Arévalo, Daniel (2003). Obligaciones. Teoría general y clasificaciones. La resolución por incumplimiento. Santiago: Editorial Jurídica de Chile.

Pereira Fredes, Esteban (2009). "Sobre la teoría de la imprevisión". La Razón del Derecho. Revista Interdisciplinaria de Ciencias Jurídicas, No 1, pp. 1-20.

Pereira Fredes, Esteban (2010a). "Contextos de participación como fundamento de la responsabilidad”. En: Causas perdidas. Ensayos de filosofia jurídica, politica y moral. Santiago: Catalonia, pp. 307-331.

Pereira Fredes, Esteban (2010b). "El contrato como promesa y su discusión contemporánea”. En Artificium. Revista Iberoamericana de Estudios Culturales y Análisis Conceptual, México D.F., Vol. 1, pp. 49-72.

Pereira Fredes, Esteban (2012). "La teoría del derecho como posibilidad. Reflexiones sobre la naturaleza y el concepto de derecho". Revista de Estudios de la Justicia, No 17, pp. 83-104.

Pereira Fredes, Esteban (2014a). “Tradición analítica de la filosofía del derecho”. En: Problemas Actuales de la Filosofía Jurídica. Santiago: Librotecnia, pp. 283322.

Pereira Fredes, Esteban (2014b). "Dos versiones sobre el fenómeno jurídico". Revista de Estudios de la Justicia, No 21 (en prensa).

Pino EmharT, Alberto (2013). "Entre reparación y distribución. La responsabilidad civil extracontractual como mecanismo de distribución de infortunios". Revista Chilena de Derecho Privado, No 21, pp. 89-135.

Pizarro Wilson, Carlos (2004). "Notas críticas sobre el fundamento de la fuerza obligatoria del contrato. Fuentes e interpretación del artículo 1545 del Código Civil chileno". Revista Chilena de Derecho, Vol. 31, No 2, pp. 225-237.

Rawls, John (1974). "Dos conceptos de reglas" [Two Concepts of Rules]. En: Teorías sobre la Ética. Arboli, Manuel (Trad.), México D.F.: Fondo de Cultura Económica, pp. 210-247.

RAZ, Joseph (1991). Razón práctica y normas [Practical Reason and Norms]. RuIz Manero, Juan (Trad.), Madrid: Centro de Estudios Constitucionales.

Rousseau, Jean-Jacques (2007). El Contrato Social o Principios de Derecho Político [Du Contrat Social]. De los Ríos, Fernando (Trad.), Madrid: Tecnos.

SCANLON, Thomas (2003). Lo que nos debemos unos a otros. ¿Qué significa ser moral? [What We Owe to Each Other]. Weikert García, Ernest (Trad.), Barcelona: Paidós. 
Schapp, Jan (1998). Derecho Civil y Filosofía del Derecho. La Libertad en el derecho. Villar Borda, Luis (Trad.), Bogotá: Universidad Externado de Colombia.

SEARLE, John (1997). La construcción de la realidad social [The Construction of Social Reality]. Domènech, Antoni (Trad.), Barcelona: Paidós.

SHARp, F. C. (1934). "The ethics of breach of contract". International Journal of Ethics, Vol. 45, No 1, pp. 27-53.

SHAVELL, Steven (2005). "Is breach of contract immoral?" Harvard Law and Economics Discussion, Paper No 531, pp. 1-28.

SHEINMAN, Hanoch (2000). "Contractual liability and voluntary undertakings". Oxford Journal of Legal Studies, Vol. 20, No 2, pp. 205-220.

Sieckmann, Jan-R (2012). The Logic of Autonomy. Law, Morality and Autonomous Reasoning. Oxford: Hart Publishing.

SMART, J. C. C. (1974). "Utilitarismo extremo y restringido" [Extreme and Restricted Utilitarianism]. En: Teorías sobre la Ética, Arboli, Manuel (Trad.), México D.F.: Fondo de Cultura Económica, pp. 248-265.

Smith, Stephen A. (2011). "The Normativity of Private Law". Oxford Journal of Legal Studies, Vol. 31, No 2, pp. 215-242.

Somarriva, Manuel (2010). "Algunas consideraciones sobre el principio de la Autonomía de la Voluntad”. En: Doctrina Civil Chilena en el Bicentenario 1810-2010. Santiago: Editorial Jurídica de Chile, pp. 107-118.

STONE, Richard (2008). The Modern Law of Contract. London \& New York: Routledge-Cavendish.

Suchman, Mark C. (2003). "The Contract as Social Artifact". Law \& Society Review, Vol. 37, No 1, pp. 91-142.

Tarello, Giovanni (1995). "Ideologías del siglo XVIII sobre la codificación y estructura de los códigos" [Le ideologie della codificazione nel secolo XVIII]. En: Cultura Jurídica y Política del Derecho. Rosas Alvarado, Isidro (Trad.), México D.F.: Fondo de Cultura Económica, pp. 39-56.

Tomás (2001). Suma de Teología. Tomos II-III, Regentes de Estudios de las Provincias Dominicanas en España (Trad.), Madrid: BAC.

Vial del Río, Víctor (2003). Teoría General del Acto Jurídico. Santiago: Editorial Jurídica de Chile.

VidAl Olivares, Álvaro (2000). "La construcción de la regla contractual en el derecho civil de los contratos". Revista de Derecho, Pontificia Universidad Católica de Valparaíso, Vol. XXI, pp. 209-227.

Waldron, Jeremy (2010). "Property Law”. En: A Companion to Philosophy of Law and Legal Theory. Oxford: Blackwell, pp. 9-28.

WeInrib, Ernest J. (2012). The Idea of Private Law. Oxford: Oxford University Press. 
Wittgenstein, Ludwig (1998). Investigaciones Filosóficas [Philosophische Untersuchungen]. García SuÁreZ, Alfonso y Moulines, Ulises (Trad.), Barcelona: Crítica.

Zipursky, Benjamin C. (2004). "Philosophy of Private Law". En: The Oxford Handbook of Jurisprudence \& Philosophy of Law. Oxford: Oxford University Press, pp. 623-655. 